U.S. Department of the Interior

U.S. Geological Survey

Prepared in cooperation with the

U.S. Environmental Protection Agency

Estimation of the Change in Freshwater Volume in the North Coast Limestone Upper Aquifer of Puerto Rico in the Río Grande de Manatí-Río de la Plata Area between 1960 and 1990 and Implications on Public-Supply Water Availability

Scientific Investigations Report 2007-5194

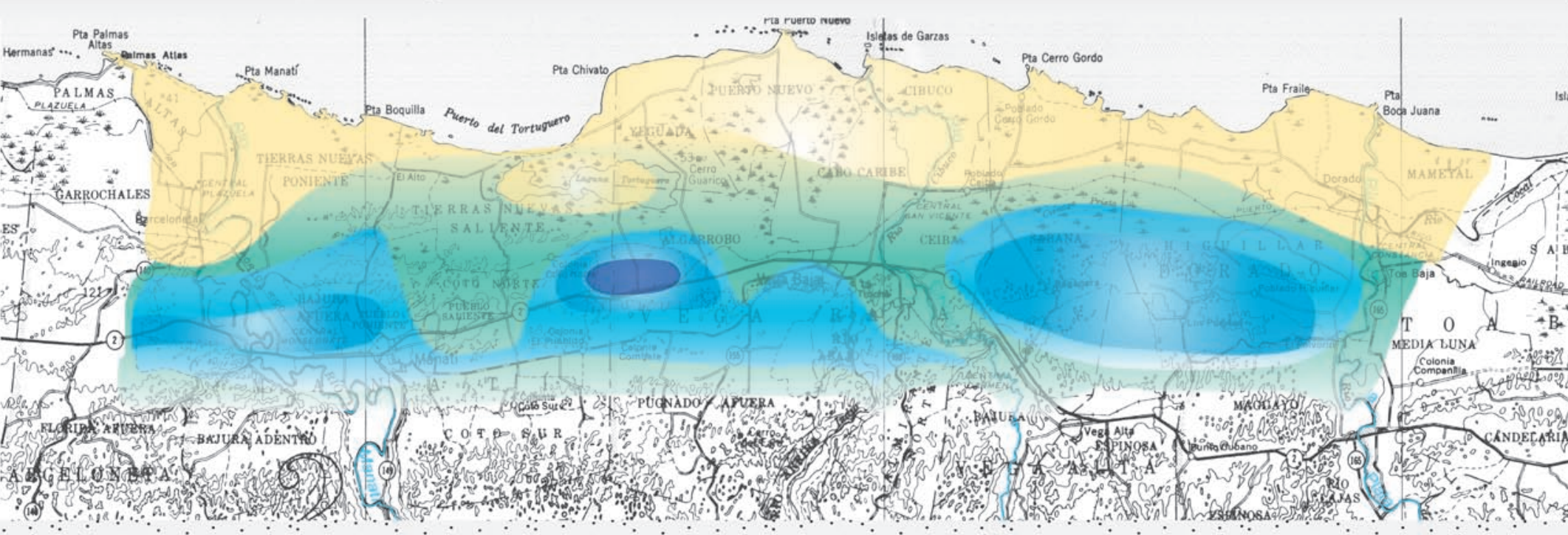





\section{Estimation of the Change in Freshwater Volume in the North Coast Limestone Upper Aquifer of Puerto Rico in the Río Grande de Manatí-Río de la Plata Area between 1960 and 1990 and Implications on Public-Supply Water Availability}

By Fernando Gómez-Gómez

Prepared in cooperation with the U.S. Environmental Protection Agency

Scientific Investigations Report 2007-5194 


\section{U.S. Department of the Interior DIRK KEMPTHORNE, Secretary \\ U.S. Geological Survey \\ Mark D. Myers, Director}

U.S. Geological Survey, Reston, Virginia: 2008

For product and ordering information:

World Wide Web: http://www.usgs.gov/pubprod

Telephone: 1-888-ASK-USGS

For more information on the USGS — the Federal source for science about the Earth, its natural and living resources, natural hazards, and the environment:

World Wide Web: http://www.usgs.gov

Telephone: 1-888-ASK-USGS

Any use of trade, product, or firm names is for descriptive purposes only and does not imply endorsement by the U.S. Government.

Although this report is in the public domain, permission must be secured from the individual copyright owners to reproduce any copyrighted materials contained within this report.

Suggested citation:

Gómez-Gómez, Fernando, 2008, Estimation of the change in freshwater volume in the North Coast Limestone Upper aquifer of Puerto Rico in the Río Grande de Manatí - Río de la Plata area between 1960 and 1990 and implications on public-supply water availability: U.S. Geological Survey Scientific Investigations Report 2007-5194, 24 p. 


\section{Contents}

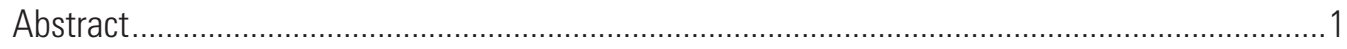

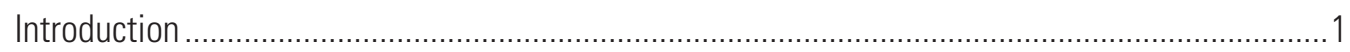

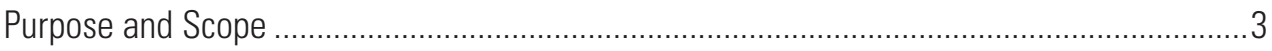

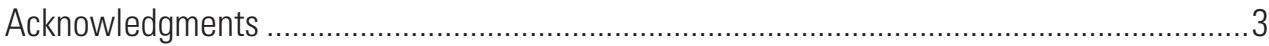

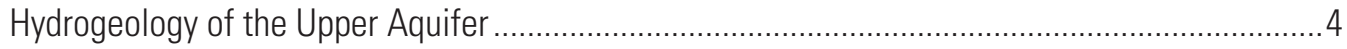

Occurrence of Ground Water and Hydraulic Characteristics .............................................. 4

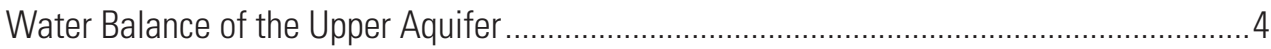

Estimated Spatial Thickness of the Freshwater Lens Pre- and Post-Development ...............10

Effects of Fresh Ground-Water Volume Depletion in the Upper Aquifer ...................................15

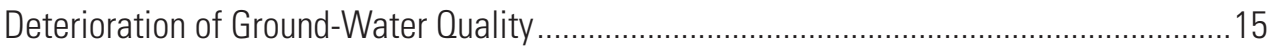

Implications of Unconstrained Ground-Water Withdrawals............................................. 15

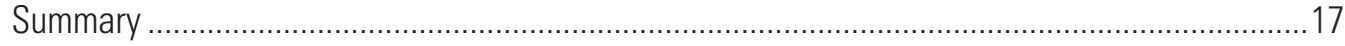

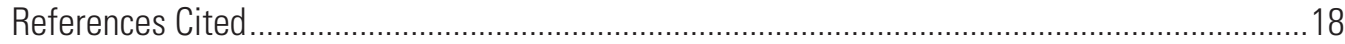

Appendix 1. Specific conductivity variation with depth of penetration during test well drilling in

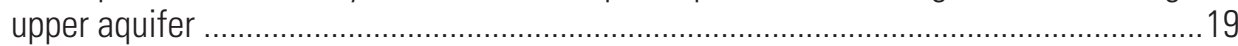

\section{Figures}

1. Map Showing extent of the North Coast Limestone aquifer system in northern Puerto

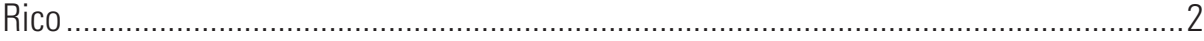

2. Map Showing surficial geology of the North Coast Limestone aquifer system in north central Puerto Rico and area of study between Barceloneta and Toa Baja,

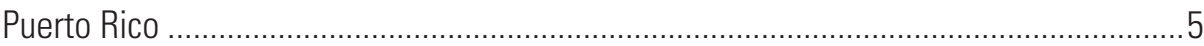

3. Graph showing (A) Long-term annual rainfall, and (B) annual rainfall deviation at Dorado, Puerto Rico, from the 64.63 inches per year normal for the 1960-89 period.

4. Graph showing annual minimum ground-water levels and trend at the Sabana Hoyos

2, Vega Alta, observation well

5. Graph showing ground-water withdrawal rates from the upper aquifer between the Río Grande de Manatí and Río Cibúco (western area) and between the Río Cibuco

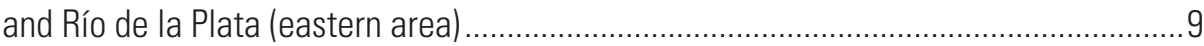

6. Cross section showing change in the thickness of the freshwater lens in the upper

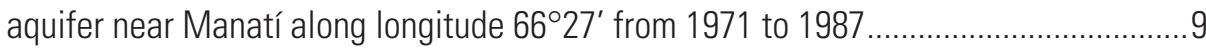

7. Graph showing specific conductivity variation with depth during test well drilling in

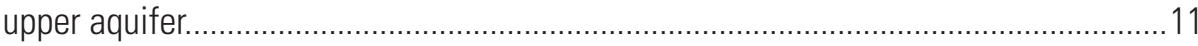

8. Map showing estimated thickness of the freshwater lens in the upper aquifer between Río Grande de Manatí and Río de la Plata area in about (A) 1960 and (B) 1990.

9. Trend in dissolved-solids concentrations at selected wells and at Ojo de Agua spring in the Barceloneta to Toa Baja area of the North Coast Limestone upper aquifer...... 


\section{Tables}

1. Generalized water budget for the upper aquifer in the area between the Río Grande de Manatí and the Río de la Plata......

2a. Locations used in development of the estimated thickness map of the freshwater lens for post-development conditions.

2b. Locations used in development of the estimated thickness map of the freshwater lens for post-development conditions

\section{Conversion Factors}

\begin{tabular}{|c|c|c|}
\hline Multiply & By & To obtain \\
\hline \multicolumn{3}{|c|}{ Length } \\
\hline inch (in.) & 2.54 & centimeter $(\mathrm{cm})$ \\
\hline foot (ft) & 0.3048 & meter $(\mathrm{m})$ \\
\hline mile (mi) & 1.609 & kilometer (km) \\
\hline \multicolumn{3}{|c|}{ Area } \\
\hline acre & 4,047 & square meter $\left(\mathrm{m}^{2}\right)$ \\
\hline square mile $\left(\mathrm{mi}^{2}\right)$ & 259.0 & hectare (ha) \\
\hline \multicolumn{3}{|c|}{ Volume } \\
\hline million gallons (Mgal) & 3,785 & cubic meter $\left(\mathrm{m}^{3}\right)$ \\
\hline cubic foot $\left(\mathrm{ft}^{3}\right)$ & 0.02832 & cubic meter $\left(\mathrm{m}^{3}\right)$ \\
\hline acre-foot (acre-ft) & 1,233 & cubic meter $\left(\mathrm{m}^{3}\right)$ \\
\hline \multicolumn{3}{|c|}{ Flow rate } \\
\hline acre-foot per year (acre-ft/yr) & 1,233 & cubic meter per year $\left(\mathrm{m}^{3} / \mathrm{yr}\right)$ \\
\hline cubic foot per second $\left(\mathrm{ft}^{3} / \mathrm{s}\right)$ & 0.02832 & cubic meter per second $\left(\mathrm{m}^{3} / \mathrm{s}\right)$ \\
\hline cubic foot per day $\left(\mathrm{ft}^{3} / \mathrm{d}\right)$ & 0.02832 & cubic meter per day $\left(\mathrm{m}^{3} / \mathrm{d}\right)$ \\
\hline gallon per day (gal/d) & 0.003785 & cubic meter per day $\left(\mathrm{m}^{3} / \mathrm{d}\right)$ \\
\hline million gallons per day (Mgal/d) & 0.04381 & cubic meter per second $\left(\mathrm{m}^{3} / \mathrm{s}\right)$ \\
\hline \multicolumn{3}{|c|}{ Hydraulic conductivity } \\
\hline foot per day (ft/d) & 0.3048 & meter per day $(\mathrm{m} / \mathrm{d})$ \\
\hline \multicolumn{3}{|c|}{ Transmissivity* } \\
\hline foot squared per day $\left(\mathrm{ft}^{2} / \mathrm{d}\right)$ & 0.09290 & meter squared per day $\left(\mathrm{m}^{2} / \mathrm{d}\right)$ \\
\hline
\end{tabular}

Density values are shown in kilograms per cubic meter $\left(\mathrm{kg} / \mathrm{m}^{3}\right)$, dissolved-solids concentrations are shown in milligrams per liter (mg/L), and specific conductance values are shown in microsiemens per centimeter at $25^{\circ} \mathrm{C}(\mu \mathrm{S} / \mathrm{cm})$. 


\title{
Estimation of the Change in Freshwater Volume in the North Coast Limestone Upper Aquifer of Puerto Rico in the Río Grande de Manatí-Río de la Plata Area between 1960 and 1990 and Implications on Public-Supply Water Availability
}

\author{
By Fernando Gómez-Gómez
}

\begin{abstract}
Ground water in the upper aquifer of the North Coast Limestone aquifer system historically has been the principal source of public-supply and selfsupplied industrial water use in north-central Puerto Rico. Development of the aquifer for these two major water-use categories began in about 1930; however, withdrawals did not become an important water-supply source for sustaining local development until the 1960s. Ground-water withdrawals averaged about 6 million gallons per day from 1948 to the mid-1960s and peaked at about 33 million gallons per day in the 1980s.

Withdrawals have since declined, averaging about 11.5 million gallons per day in 2002. Aquifer contamination by industrial chemical spills and by nitrates from agricultural and domestic sources initially reduced pumpage for public-supply use within localized areas, leading eventually to increased withdrawals at unaffected well fields.

The long-term effect of unconstrained groundwater withdrawals has been a regional thinning of the freshwater lens in an area encompassing 50,600 acres between the Río Grande de Manatí and Río de la Plata, generally north of latitude $18^{\circ} 25^{\prime}$. The effects of aquifer overdraft have been documented in the regional thinning of the freshwater lens, with an increase in dissolved-solids concentration in ground-water wells. Dissolved-solids concentration in public-supply wells were generally between 250 and 350 milligrams per liter during the $1960 \mathrm{~s}$, but increased to greater than 500 milligrams per liter in virtually all of the wells by 2000 .

Depletion of fresh ground water was estimated at 282,000 acre-feet: 103,000 acre-feet in the Río Grande de Manatí to Río Cibuco area between 1960 and 1995, and 179,000 acre-feet in the Río Cibuco to Río de la
\end{abstract}

Plata area between 1960 and 1992. Thus, aquifer freshwater volume depletion below mean sea level datum may have contributed as much as 38 percent (7.5 million gallons per day) of the 20-million gallons per day average withdrawal rate during the stated time periods. The calculated depletion of aquifer freshwater volume is equivalent to an average long-term rate of 8,400 acre-feet per year. Aquifer withdrawals can be anticipated to decline to about 10 million gallons per day by 2010 at the projected trend of well closures. The lost supply would have to be compensated from surface-water sources because the part of the North Coast Limestone aquifer system south of latitude $18^{\circ} 25^{\prime}$, although less vulnerable to saline-water encroachment, is not as productive.

\section{Introduction}

The North Coast Limestone aquifer system is one of the most productive sources of ground water in Puerto Rico and consists of the upper aquifer, a confining unit, and the lower aquifer. The upper aquifer is the principal source of fresh ground water in the five communities of Barceloneta, Manatí, Vega Baja, Vega Alta, and Dorado in north-central Puerto Rico (fig. 1). Over the past century, the upper aquifer has been negatively impacted by large-scale reclamation and construction of drainage projects throughout the region. This problem has been further worsened by aquifer overdraft and increased ground-water withdrawals that have caused degradation of water quality, salinewater encroachment from the coast, and thinning of the freshwater lens. 


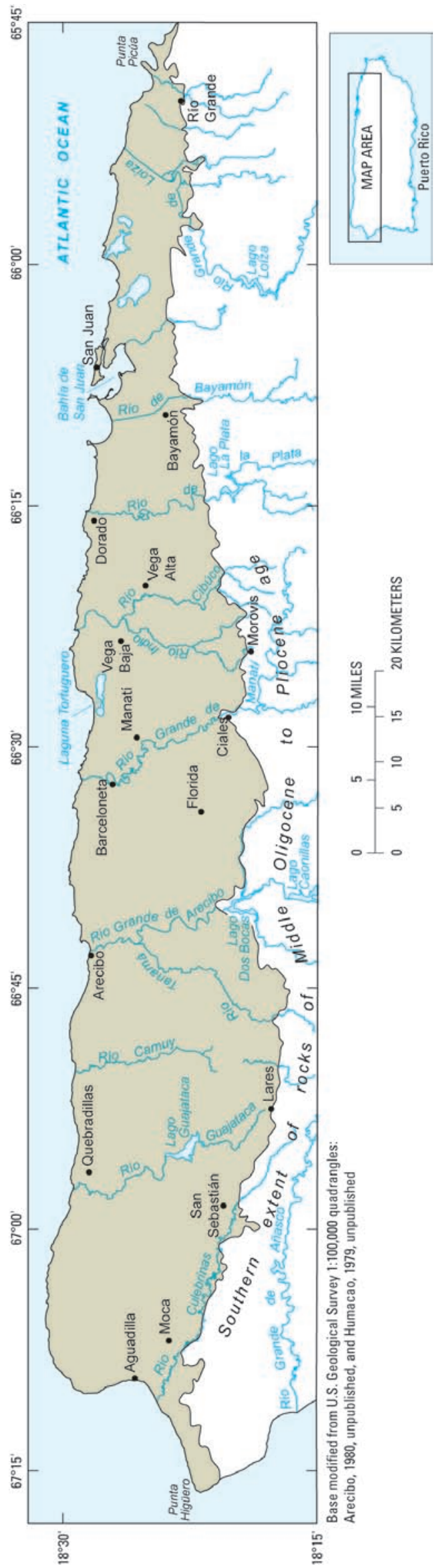

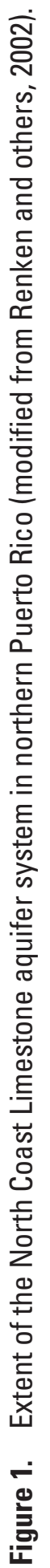


Development of the upper aquifer as a source of public-supply and self-supplied industrial water use began in about 1930. During the 1940s, withdrawals for these two major water-use categories were estimated at less than 2.5 million gallons per day $(\mathrm{Mgal} / \mathrm{d})$, with about $1.5 \mathrm{Mgal} / \mathrm{d}$ accounting for public-supply use and $1.0 \mathrm{Mgal} / \mathrm{d}$ accounting for self-supplied industrial use. Ground-water withdrawals increased rapidly after the 1960s, reaching a maximum of about $33 \mathrm{Mgal} / \mathrm{d}$ during the 1980s. Since that time, withdrawals from the upper aquifer have been declining. Consequently, degradation of ground-water quality from industrial chemical spills (U.S. Environmental Protection Agency, 2004a; 2004b) and nitrate contamination from agricultural and domestic sources (Conde-Costas and Gómez-Gómez, 1999) have reduced the capacity of the upper aquifer to meet the water-supply demands of the five communities in north-central Puerto Rico. Near Barceloneta, the lost production at public-supply wells has been primarily compensated by the construction of new wells (greater than 1,000 feet deep) that penetrate the lower aquifer (also locally referred to as the "artesian aquifer" near the coast). East of Barceloneta, public-supply groundwater production has been compensated primarily by increasing ground-water withdrawals from the upper aquifer at unaffected wells because the lower aquifer is substantially less productive and wells must penetrate the aquifer at depths greater than 2,000 feet.

East of the Río Grande de Manatí, increased pumping at existing wells in the upper aquifer has caused saline-water encroachment, which principally is evidenced by the increases in dissolved-solids, hardness, and chloride concentrations. The increases generally are subtle, and probably a result of upconing of saline water near the freshwater/seawater interface. However, these subtle increases can be discerned by domestic users of the public-supply system in the formation of scale in plumbing fixtures, greater use of detergents, the unpalatable taste of drinking water, stain marks on washed vehicles, and the need to install household water softening units to address the degraded water quality.

Ground-water depletion as a result of sustained pumping has been a major concern in Puerto Rico for many years. To address this concern, the U.S. Geological Survey, in cooperation with the U.S. Environmental Protection Agency, conducted a study to evaluate ground-water withdrawals and the effects on depletion of storage in the upper aquifer in Puerto Rico from predevelopment time to the present. The regional assessment was made for an area in north-central Puerto Rico that encompasses about 50,600 acres, where ground-water withdrawals have been the major source of public-supply water use to an estimated population of about 178,000 people (Molina-Rivera, 2005). The results of the study will provide water managers and others with the necessary information to improve knowledge on ground-water flow in the upper aquifer, especially the relative importance of aquifer recharge, streamflow infiltration, and reduced ground-water flow to natural discharge features.

\section{Purpose and Scope}

The purpose of this report is to evaluate the availability of public-supply water in the upper aquifer in north-central Puerto Rico and the changes that have taken place as a result of ground-water withdrawals over the last century. Specifically, this report describes the occurrence of ground water in the upper aquifer, estimates the water balance and spatial thickness of the freshwater lens in the aquifer, documents historical regional changes in ground-water quality in publicsupply wells and its relation to the spatial thinning of the freshwater lens, and describes the implications of unconstrained ground-water withdrawals. The water balance of the upper aquifer was estimated by development of numerical models that simulate conditions in the areas between the Río Grande de Manatí and Río Cibuco and between the Río Cibuco and Río de la Plata. The historical record was evaluated at an observation well to determine ground-water level trends in the aquifer over time. Average ground-water withdrawal rates from the upper aquifer were determined for the area between the Río Grande de Manatí and the Río de la Plata by decade from the 1940s to 1990s (and estimated for 2002). Maps were constructed using various sources of literature and data to estimate the regional spatial thickness of the freshwater lens in the upper aquifer for pre-development and post-development assuming static equilibrium will be reached. Finally, to evaluate trends in water quality, dissolved-solids concentrations were determined in samples collected from 1950 to 2005 in selected wells that penetrate the upper aquifer.

\section{Acknowledgments}

The author is grateful to Ms. Claudia Gutierrez of the U.S. Environmental Protection Agency, Region II, New York, for her interest on this effort as part of the Regional Geographic Initiative Program. Special thanks also is extended to René García formerly of the U.S. Geological Survey, New Mexico Water Science Center, and Sigfredo Torres-González of the U.S. Geological Survey, Caribbean Water Science Center, for their initiative in the development of a ground-water/sourcewater-protection program in Puerto Rico. 


\section{Hydrogeology of the Upper Aquifer}

The North Coast Limestone aquifer system consists of a thick sequence of carbonate rocks of Miocene to Oligocene age (fig. 2). This aquifer system, which extends about 90 miles (mi) along the northern coast of Puerto Rico and encompasses an area of almost 700 square miles $\left(\mathrm{mi}^{2}\right)$, consists of two aquifers separated by a confining unit (Renken and others, 2002). The confining unit in the middle of the aquifer system is formed primarily by the upper unnamed member of the Cibao Formation (undivided), and a mudstone unit that seems to be present only in the subsurface near Manatí. The mostly unconfined upper aquifer (the focus of this report) primarily consists of the Aymamón and Aguada (Los Puertos) Limestones. The lower aquifer is composed primarily of the Montebello Limestone Member of the Cibao Formation and the Lares Limestone.

\section{Occurrence of Ground Water and Hydraulic Characteristics}

The upper aquifer encompasses an area of about $430 \mathrm{mi}^{2}$ in northern Puerto Rico, but is most productive between Barceloneta and Toa Baja (fig. 2). In this region, the upper aquifer underlies the coastal area generally northward of latitude $18^{\circ} 24^{\prime}$ and is extensive throughout the alluvial valleys of the lower Río Grande de Manatí, Río Indio, Río Cibuco, and Río de la Plata (fig. 2).

Generally, northward of about latitude 18 $26^{\prime}$, the upper aquifer exists primarily as a lens of freshwater "floating" above saltwater with aquifer heads varying from about $10 \mathrm{ft}$ to near sea level at the coast (Torres-Sierra, 1985; Conde-Costas and Rodríguez, 1997; Sepúlveda, 1999). Inland from about latitude $18^{\circ} 24^{\prime} 30^{\prime \prime}$, the Aguada Limestone is mostly unsaturated and ground-water flow exists primarily as conduit or thin "sheet-like" flow above the underlying Cibao Formation, which constitutes the relatively impermeable base of the upper aquifer (Bennett and Guisti, 1972). An exception to this condition is to the east of the Río Cibuco, where the Aguada Limestone is saturated and is in hydraulic connection with the underlying Cibao Formation and older carbonate units. The transmissivity of the upper aquifer east of the Río Cibuco in areas inland from latitude $18^{\circ} 25^{\prime}$, however, is less than 200 feet squared per day $\left(\mathrm{ft}^{2} / \mathrm{d}\right)$ with wells typically yielding less than 50,000 gallons per day (gal/d). Northward from latitude $18^{\circ} 25^{\prime}$, the transmissivity in the freshwater part of the upper aquifer throughout the region ranges from 10,000 to $150,000 \mathrm{ft}^{2} / \mathrm{d}$ with public supply well yields ranging from 300,000 to $1,500,000 \mathrm{gal} / \mathrm{d}$. In the alluvial valleys, alluvium consists predominately of fine-grained deposits with a low to moderate hydraulic conductivity (less than 30 feet per day (ft/d)), and wells must penetrate the underlying limestone units to obtain yields greater than $150,000 \mathrm{gal} / \mathrm{d}$.

\section{Water Balance of the Upper Aquifer}

The water balance of the upper aquifer has been estimated by development of finite-difference digital ground-water flow models tested under transient conditions between the Río Grande de Manatí and Río Cibuco area (Cherry, 2001) and between the Río Cibuco and Río de la Plata area (Gómez-Gómez and TorresSierra, 1988; Sepúlveda, 1999). These two sub-areas will be referred to throughout the report as the "western area" for the part of the upper aquifer between the Río Grande de Manatí and Río Cibuco, and the "eastern area" for the part of the aquifer between the Río Cibuco and Río de la Plata. The aquifer models were used to improve estimates of ground-water recharge rates and discharge sinks. The ground-water recharge rates were derived from spatial rainfall runoff infiltration and streamflow seepage. Discharge sinks are represented as aquifer flow to: (1) natural discharge features such as wetlands, streams, and the seabed near the coastline; and (2) man-made modifications to the flow system, such as withdrawals from wells and coastal drainage works. The aquifer flow models were calibrated for near-present conditions, using data that included the spatial distribution of aquifer water levels and water budgets such as discharge rates from wells, outflow from the relatively freshwater Laguna Tortuguero (fig. 1) to the sea, and stream baseflow measurements. Adequate data sets used to develop the digital groundwater flow models were available for the eastern area in 1983 and 1992 and for the western area in 1995. These aquifer models were used to simulate the historical changes of the water table and the effects that groundwater withdrawals for public-supply and self-supplied industrial uses have had on the ground-water flow system (table 1).

Although the developed aquifer models have contributed to improving the knowledge on the occurrence and movement of ground water, the constructed digital flow models had two major assumptions that limit their use to anticipate future changes. Among the most important assumptions used in the digital models developed to date are: (1) a static freshwater-saltwater interface was assumed to be present beneath the freshwater lens for the calibration period used and also throughout the historical simulation periods, which averaged 60 years; and (2) aquifer recharge was assumed to be constant throughout the entire simulation period, although recharge may vary substantially from average, especially during excessively wet years and during years with rainfall deficiency at or 

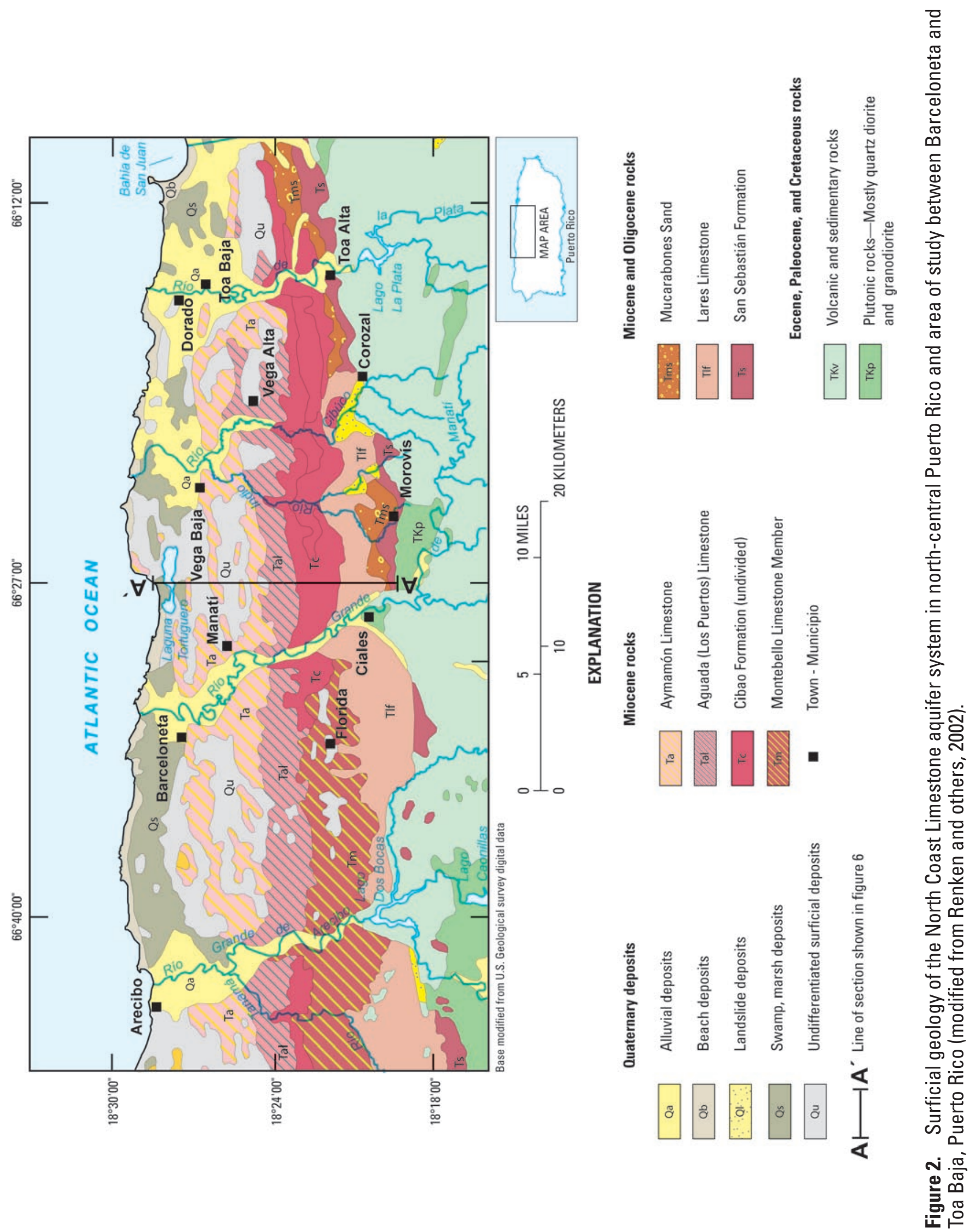
Table 1. Generalized water budget for the upper aquifer in the area between the Río Grande de Manatí and the Río de la Plata.

[Pre-development water budgets from digital ground-water flow models by Gómez-Gómez and Torres-Sierra (1988) for the eastern area and Cherry (2001) for the western area; budget terms rounded to nearest 0.5 cubic feet per second $\left(\mathrm{ft}^{3} / \mathrm{s}\right)$; acre-ft/yr, budget terms expressed in acre feet per year. Budget terms for the end of simulation of transient models: 1983 for the eastern area and 1995 for the western area; for the eastern area budget terms at end of 1983 assumed valid also for early 1990s. Budget terms at end of transient simulations were at new steady-state conditions, no significant change in storage.]

\begin{tabular}{|c|c|c|}
\hline Recharge to aquifer from: & $\begin{array}{c}\text { Pre-development } \\
\text { (prior to about 1940), } \\
\text { in } \mathrm{ft}^{3} / \mathrm{s} \text { (acre-ft/yr) }\end{array}$ & $\begin{array}{c}\text { Post-development } \\
\text { (estimate for conditions } \\
\text { in early 1990s), } \\
\text { in } \mathrm{ft}^{3} / \mathrm{s} \text { (acre-ft/yr) }\end{array}$ \\
\hline Rainfall/runoff from inland of latitude $18^{\circ} 25^{\prime}$ & $1.5(1085)$ & $1.5(1085)$ \\
\hline \multicolumn{3}{|l|}{ River infiltration } \\
\hline Río Grande de Manatí & $2.5(1810)$ & $7.5(5430)$ \\
\hline Río Cibuco and Río Indio & $1(725)$ & $6(4340)$ \\
\hline Río de la Plata & 0 & 0 \\
\hline Areal rainfall/runoff infiltration & $55(39,800)$ & $55(39,800)$ \\
\hline Total recharge to aquifer & $60(43,420)$ & $70(50,670)$ \\
\hline \multicolumn{3}{|l|}{ Discharge from aquifer to: } \\
\hline \multicolumn{3}{|l|}{ Wetlands } \\
\hline Laguna Tortuguero & $4(2890)$ & $3(2170)$ \\
\hline Cienaga Prieta & $15(10,860)$ & $3(2170)$ \\
\hline Caño Las Pozas \& Cabo Caribe & $5(3620)$ & $3(2170)$ \\
\hline Coastal springs & $16(11,580)$ & $7(5070)$ \\
\hline \multicolumn{3}{|l|}{ Streams } \\
\hline Río Grande de Manatí & $7.5(5430)$ & $5(3620)$ \\
\hline Río Cibuco and Río Indio & $6.5(4700)$ & $2(1450)$ \\
\hline Río de la Plata & $3(2170)$ & $1(725)$ \\
\hline Atlantic Ocean & $3(2170)$ & $1(725)$ \\
\hline Ground-water withdrawals & 0 & $45(32,570)$ \\
\hline Total discharge from aquifer & $60(43,420)$ & $70(50,670)$ \\
\hline
\end{tabular}

greater than 20 percent of the 30 -year normal rainfall. Drought years in this region typically have had rainfall deficits from 20 to 34 percent below the 30-year normal (fig. 3).

The consequence of using a constant-density transient freshwater model with a static freshwaterseawater interface is that the final change in freshwater volume of the aquifer after development and a new static equilibrium is achieved would show change in storage from water-level decline, but would not show the change in volume of freshwater in the aquifer. It is important to note that it may take 100 years for the new static equilibrium to be achieved; however, deteriorating waterquality conditions may occur well before the freshwaterseawater interface reaches a new static equilibrium as evidenced from the total dissolved solids data. The consequence of assuming a constant aquifer recharge rate is that aquifer recharge equal to or greater than that occurring during an average rainfall year can take place within short time periods. Examples of intense rainfall that occurred in north-central Puerto Rico include: a stalled cold front during December 11-15, 1981, and the passage of Hurricane Hortense during September 9-10, 1996. The cold front contributed between 14 and 26 inches (in.) of rainfall - equivalent to 20 and 40 percent, respectively, of the mean annual rainfall- along the part of the upper aquifer under consideration in this study, causing ground-water levels to rise by as much as $8 \mathrm{ft}$. The hurricane contributed from 8 to 12 in. of rainfall, causing ground-water levels to rise by as much as $3 \mathrm{ft}$ (Gómez-Gómez, 1997). During above-average rainfall years (rainfall greater than 60 in. along the coast and 70 in. at inland parts of the upper aquifer), aquifer discharge to natural discharge features, such as wetlands, and to wells is more than compensated by recharge, and loss of aquifer storage is either insignificant or reversed. 

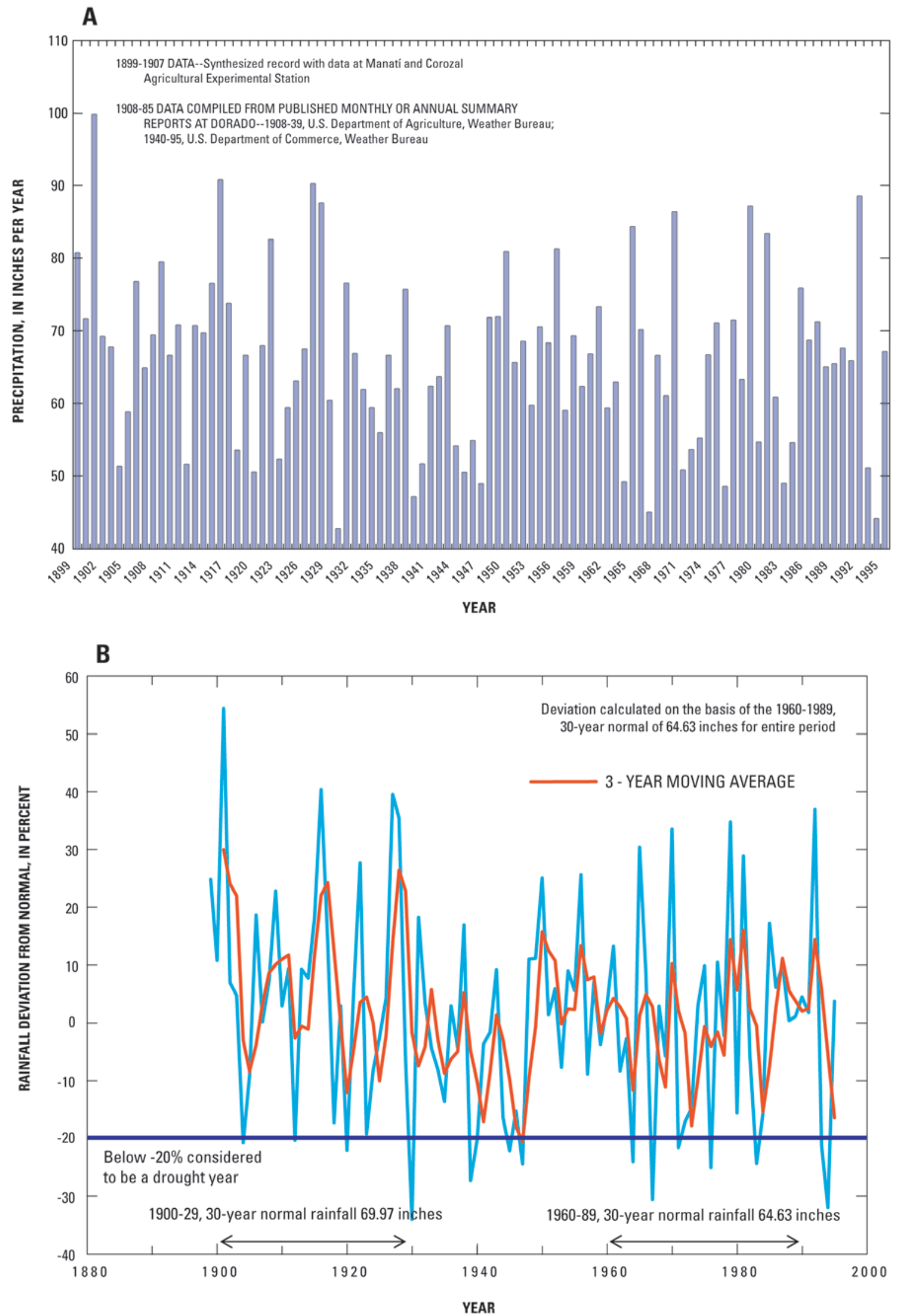

Figure 3. (A) Long-term annual rainfall, and (B) annual rainfall deviation at Dorado, Puerto Rico, from the 64.63 inches per year normal for the 1960-89 period. 
The opposite condition of little to no aquifer recharge also occurs during drought years. Over the course of the 20th century, 12 drought years were identified in the climatological data records (189995) from the U.S. Department of Agriculture and the U.S. Department of Commerce weather bureaus near Dorado (fig. 3). The precipitation data also indicate two periods when the annual rainfall amount was substantially below average during 3 consecutive years: a 3-year period ending in 1946 and another 3-year period ending in 1973. The moving average for both 3 -year periods indicates an average rainfall deficit of 18 percent below the 1960-89 normal rainfall amounts of 64.63 in. Because aquifer discharge is not compensated by recharge during drought years, aquifer discharge to natural systems (primarily wetlands) and to wells in this region is mostly derived from depletion of aquifer storage. The loss of aquifer storage that sometimes occurs may be replenished by wetter-than-average years, as can be inferred from the long-term trend of rainfall near Dorado and the annual minimum groundwater levels in the Sabana Hoyos observation well between 1960 and 2000. This well provides the longest continuous historical record of change in aquifer ground- water levels in the Dorado-Vega Alta area (fig. 1), with levels declining from about $12.5 \mathrm{ft}$ above mean sea level in 1960 to about $7 \mathrm{ft}$ above mean sea level in 2001 (fig. 4).

The water-level record in the Sabana Hoyos observation well indicates that the water table had been relatively unchanged between 1948 (earliest water-level measurements at this station) to about the mid-1960s, when ground-water withdrawals in the eastern area averaged about $4 \mathrm{Mgal} / \mathrm{d}$ (fig. 5). After the mid-1960s, total withdrawals increased to about $33 \mathrm{Mgal} / \mathrm{d}$ in the $1980 \mathrm{~s}$ and declined to about $27.5 \mathrm{Mgal} / \mathrm{d}$ during the 1990s. Although, coastal dewatering works may have been the initial cause of a lowering of the water table in coastal areas such as in the vicinity of Laguna Tortuguero prior to the 1960s (Bennet and Giusti, 1972) and in the coastal wetlands in the Dorado-Vega Alta area in the early 1960s (Gómez-Gómez and Torres-Sierra, 1988) in general, most of the decline can be ascribed to regional aquifer overdraft (Conde-Costas and Rodríguez, 1997; Cherry, 2001; and Gómez-Gómez and TorresSierra, 1988).

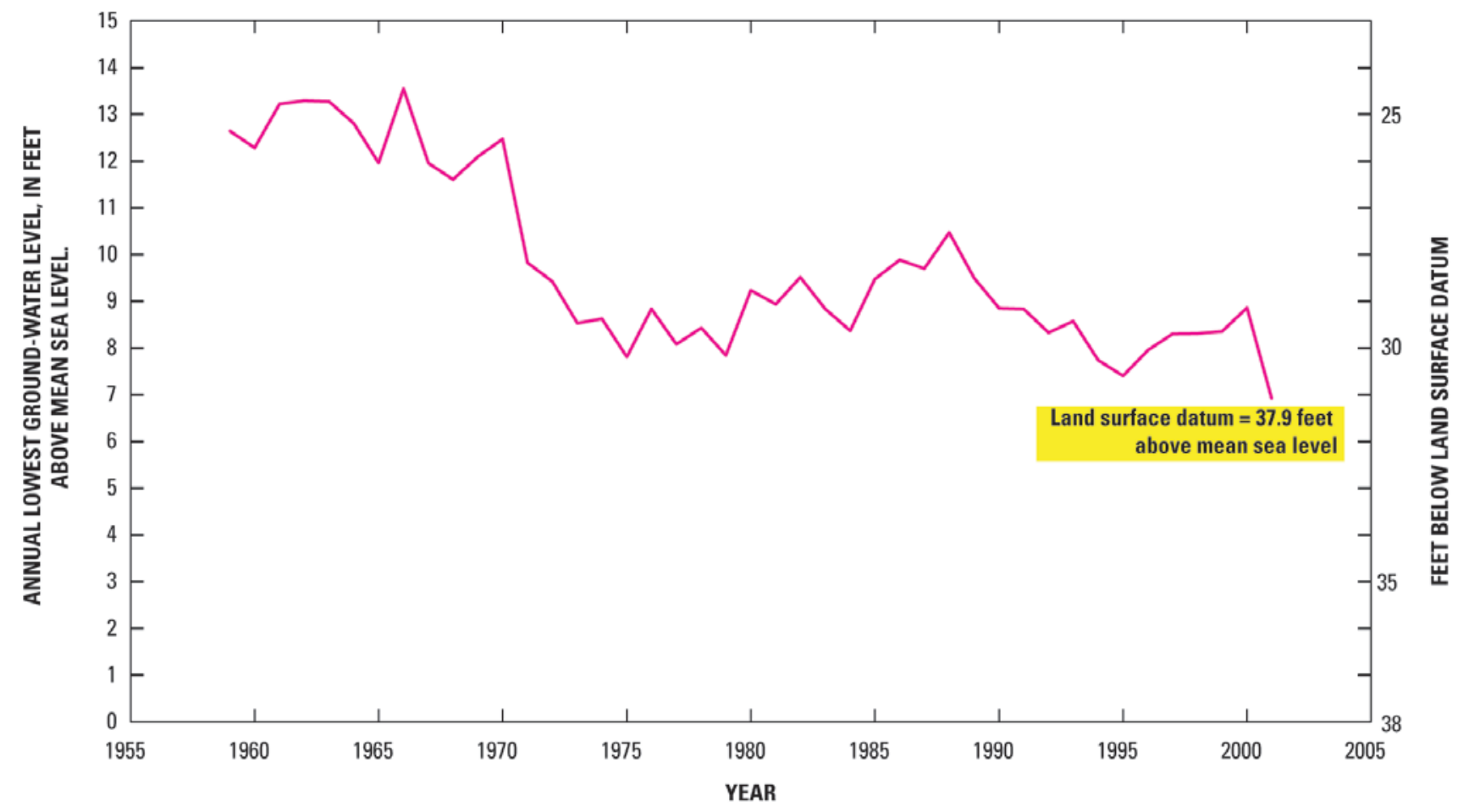

Figure 4. Annual minimum ground-water levels and trend at the Sabana Hoyos 2, Vega Alta, observation well. This well is considered representative of the ground-water level trend in part of the upper aquifer between the Río Cibuco and Río de la Plata area. 


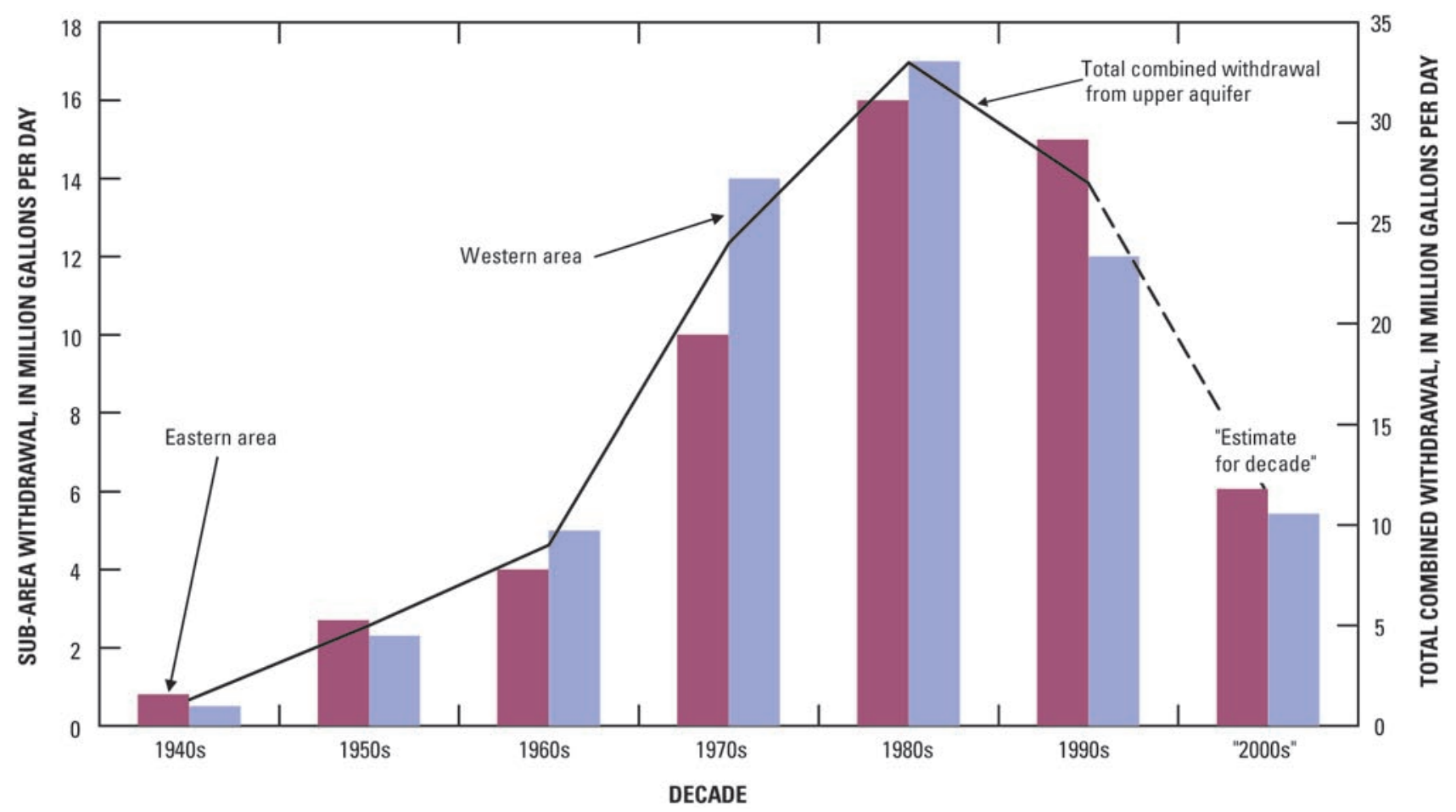

Figure 5. Ground-water withdrawal rates from the upper aquifer between the Río Grande de Manatí and Río Cibuco (western area) and between the Río Cibuco and Río de la Plata (eastern area). Average by decades from the 1940s to 1990s and estimated for 2000s.

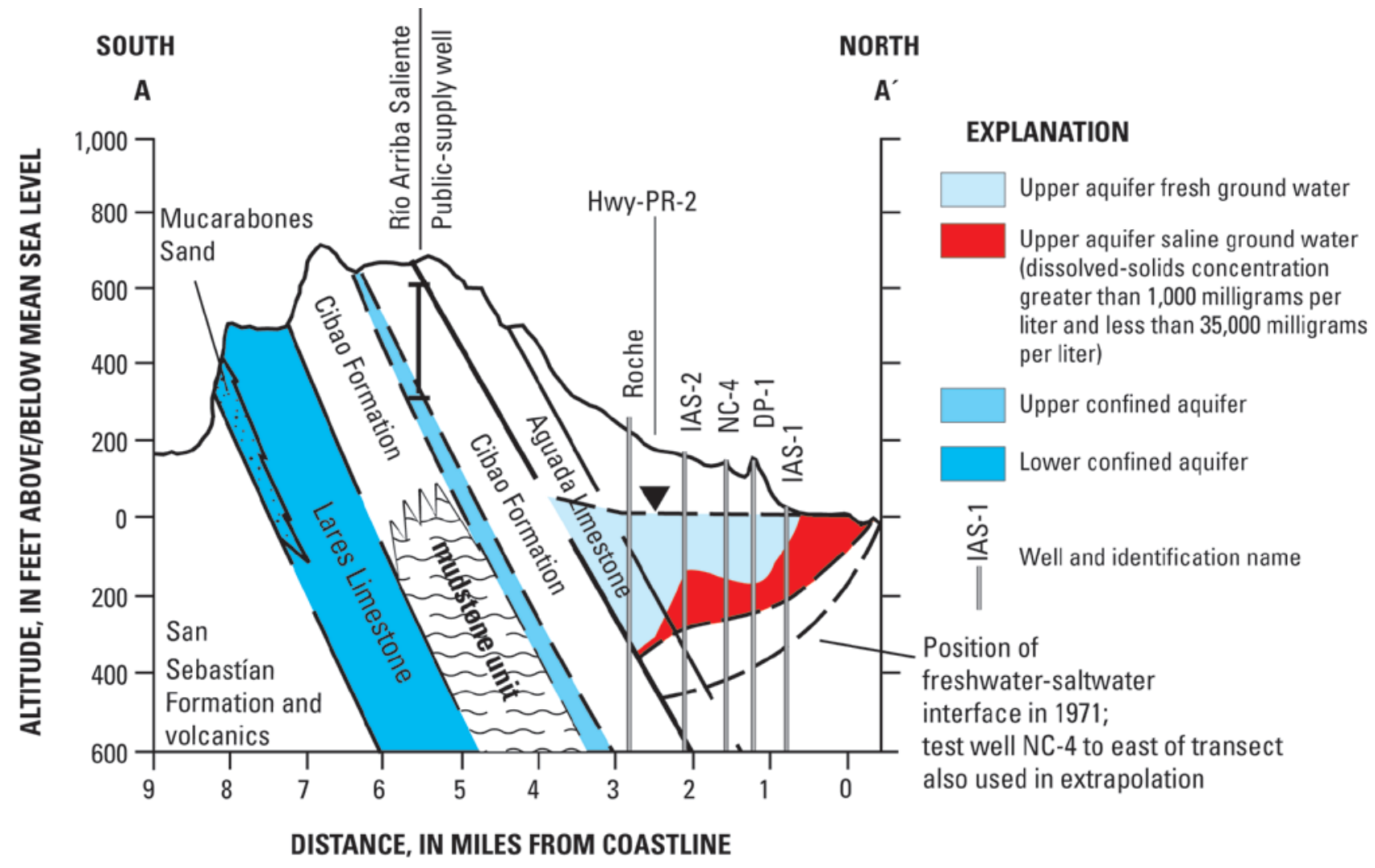

Figure 6. Change in the thickness of the freshwater lens in the upper aquifer near Manatí along longitude $66^{\circ} 27^{\prime}$ from 1971 to 1987 (modified from Conde-Costas and Gómez-Gómez, 1999). The test wells are located in the vicinity of Laguna Tortuguero near Manatí. Location of the line of section is shown in figure 2. 
Because most of the potable water in the upper aquifer exists as a lens of freshwater "floating" above saltwater, the thickness of the lens has diminished in an amount that can be estimated by the GhybenHerzberg relation (described in the next section), which is used to predict the thickness of a freshwater lens in a homogeneous (isotropic) porous media (Fetter, 1980). In the vicinity of Laguna Tortuguero, the freshwater lens was found to be as much as $400 \mathrm{ft}$ thick in 1971, when wells were first drilled to tap confined aquifers at depth, but was only $165 \mathrm{ft}$ thick in 1987 when the U.S. Geological Survey conducted test drilling in the area (Rodríguez-Martínez and others, 1992) (fig. 6).

\section{Estimated Spatial Thickness of the Freshwater Lens Pre- and Post-Development}

The regional thickness of the freshwater lens in the upper aquifer can be estimated at specific locations by use of the Ghyben-Herzberg relation (Fetter, 1980):

$$
\begin{aligned}
& \mathrm{b}=\mathrm{h}+\mathrm{z} \\
& \mathrm{z}=\left(\frac{\mathrm{e}_{\mathrm{f}}}{\mathrm{e}_{\mathrm{s}}-\mathrm{e}_{\mathrm{f}}}\right)
\end{aligned}
$$

where,

b is the thickness of the freshwater lens, in feet;

$\mathrm{h}$ is the altitude of the water table above mean sea level, in feet;

$\mathrm{z} \quad$ is the depth to the saltwater interface below mean sea level, in feet;

$e_{f} \quad$ is the density of freshwater, in kilograms per cubic meter; and

$\mathrm{e}_{\mathrm{s}} \quad$ is the density of saltwater, in kilograms per cubic meter.

The Ghyben-Herzberg relation is valid for systems in static-equilibrium. It may take hundreds of years for the freshwater-seawater interface to reach equilibrium after a water-level change. For the purposes of estimating the thickness of the freshwater lens in 1960 and 1990, static equilibrium is assumed. The 1960 map was considered to represent the estimated thickness of the freshwater lens for pre-development conditions and the 1990 map to represent post-development conditions.

The assumption is made that water levels will remain lower at post-development for a long enough period, so that a new static equilibrium of the freshwaterseawater interface is achieved. In cross-sectional variable density simulation of the high permeability, carbonate Biscayne aquifer in south Florida, it took 50 years for the freshwater-seawater interface to move inland and reach a new static equilibrium given a 1-ft lowering in canal stage boundary and 90 years for the freshwater-seawater interface to move out and reach a new equilibrium after a $1-\mathrm{ft}$ rise in canal stage boundary (Dausman and Langevin, 2004).

Although the Ghyben-Herzberg relation assumes that the change in water level has occurred for a long enough period of time that a new static-equilibrium has been achieved, 30 years may not be enough time for a new static equilibrium in the area of study. However, this equation provides a good approximation of the thickness of the freshwater lens ground water with dissolved-solids concentrations less than 1,000 milligrams per liter $(\mathrm{mg} /$ L)-by assuming density values of 1,000 kilogram per cubic meter $\left(\mathrm{kg} / \mathrm{m}^{3}\right)$ for $\mathrm{e}_{\mathrm{f}}$, and $1,025 \mathrm{~kg} / \mathrm{m}^{3}$ for $\mathrm{e}_{\mathrm{s}}$ or that typical of seawater. Potentiometric-surface and specific conductance data obtained during drilling of test wells, which penetrated the freshwater-saltwater transition zone in the upper aquifer in 1986-87 (A. Torres-González and others, U.S. Geological Survey, written commun., 1987), 1993-95 (Troester, 1999; Sepúlveda, 1999), and U.S. Geological Survey, Caribbean Water Science Center records (fig. 7), indicated the following:

(1) The fresh-to-saline transition zone was only tens of feet thick;

(2) Although aquifer development in 1960-86 caused a substantial upward displacement of the interface in the coastal area to the south of the Laguna Tortuguero, the transition zone in saline ground water with dissolved-solids concentrations ranging between 1,000 and $5,000 \mathrm{mg} / \mathrm{L}$ was also only tens of feet thick; and

(3) The depth at which the specific conductance in ground water was about 1,800 microsiemens per centimeter at $25^{\circ} \mathrm{C}(\mu \mathrm{S} / \mathrm{cm})$ (or equivalent to a dissolved-solids concentration of about $1,000 \mathrm{mg} / \mathrm{L}$ in the upper aquifer) could be predicted by assuming values as indicated for $\mathrm{e}_{\mathrm{f}}$ and $\mathrm{e}_{\mathrm{s}}$.

The absence of a substantially thick freshwatersaltwater transition zone in the study area indicates that possibly, as a result of the high transmissivity in the upper aquifer and withdrawals never exceeding the mean annual recharge rate for an extended period of time (decades), the ground-water flow pattern has not been greatly modified in the horizontal plane to cause a diffuse freshwater-to-saltwater transition zone in the vertical axis in the order of hundreds of feet. Diffuse transition zones in the order of hundreds of feet were observed at several of the test wells and only where dissolved solids concentrations exceeded 5,000 $\mathrm{mg} / \mathrm{L}$ as shown in figure 7.

Various sources of data were used to construct a map and estimate the thickness of the freshwater lens for aquifer conditions in the western area (Río Grande de Manatí to Río Cibuco) and in the eastern area (Río Cibuco to Río de la Plata) prior to large-scale development in the 1960s (about 1960) (fig. 8A). These 


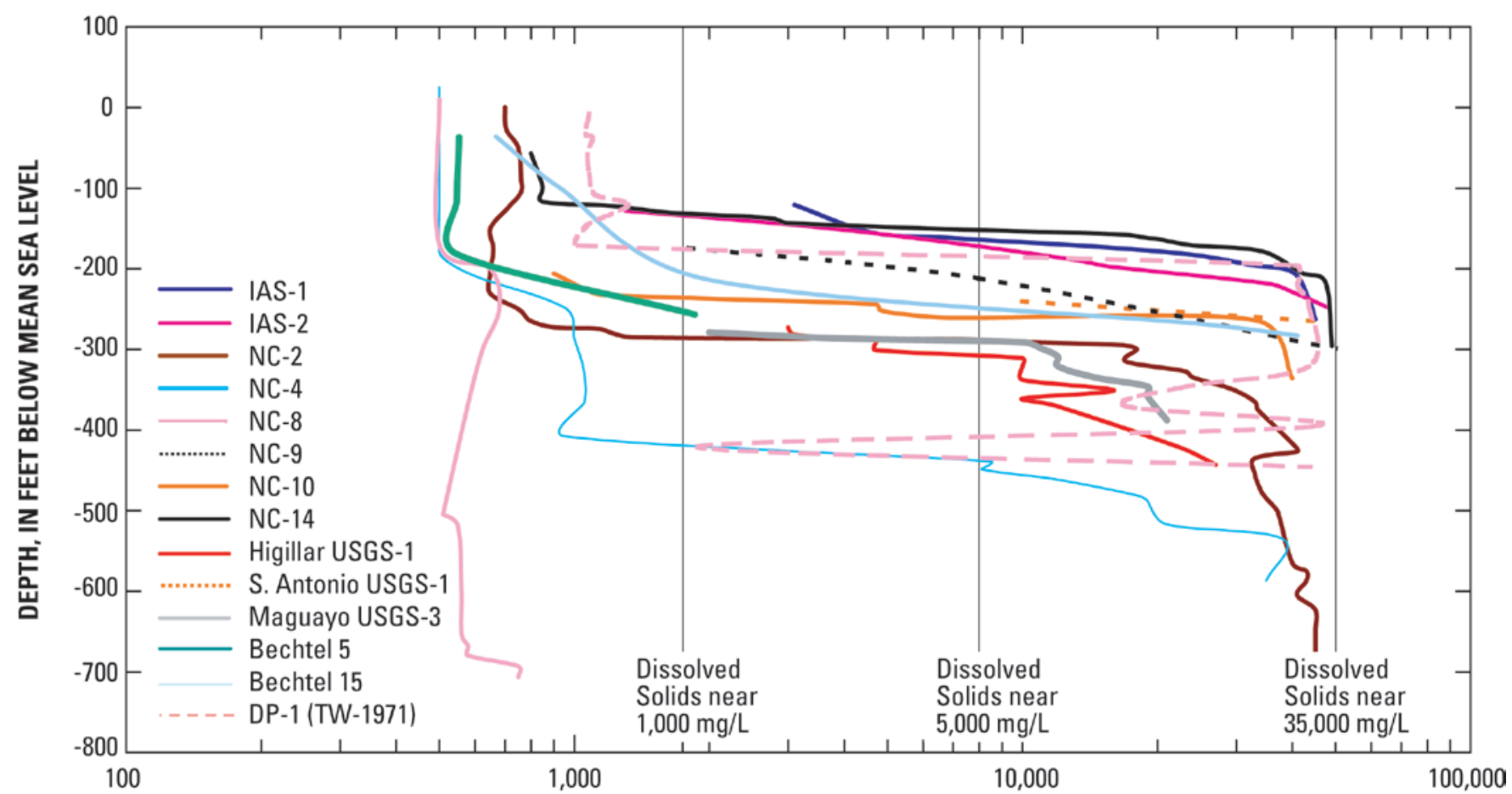

SPECIFIC CONDUCTIVITY, IN MICROSIEMENS PER CENTIMETERS AT $25^{\circ} \mathrm{C}$

Figure 7. Specific conductivity variation with depth during test well drilling in upper aquifer (refer to table $2 \mathrm{a}$ and $2 \mathrm{~b}$ and figure $2 \mathrm{~A}$ and $2 \mathrm{~B}$ for site locations).

sources include: direct-current surface resistivity surveys in the Río Grande de Manatí lower valley (GómezGómez, 1984), water levels from well completion reports provided by drillers (in U.S. Geological Survey, Caribbean Water Science Center files), and surface-water altitude in coastal wetlands (from the 1:30,000 scale U.S. Geological Survey quadrangles originally developed at a scale of 1:10,000) (table 2A). A second and similar map (fig. 8B) representing conditions in the 1990s (about 1990) was developed from: (a) available potentiometricsurface maps, prepared with third-order leveling to wells in the western area for conditions in 1995 (Conde-Costas and Rodríguez, 1997), and the eastern area for conditions in 1992 (Sepúlveda, 1999) (table 2B); and (b), drilling logs documenting the change of specific conductivity with depth for test wells drilled to depths beneath freshwater (specific conductivity greater than 1,800 $\mu \mathrm{S} / \mathrm{cm}$ at $25^{\circ} \mathrm{C}$; fig. 7). Since the historical variation of water levels in the study area has only been documented from stage changes in Laguna Tortuguero in the western area and at a well (USGS Sabana Hoyos 2 observation well) in the eastern area no effort was made to estimate the storage change in the aquifer caused by water-level lowering between pre- and post-development conditions.

A calculation of the amount of fresh ground water available in the aquifer below sea level datum was made using a porosity of 0.10 (Ward and others, 1991; Gómez-Gómez, 1997). Freshwater volume depletion was calculated using a Geographic Information System (GIS) from a triangular irregular network (TIM) prepared at a scale of 1:20,000 showing the estimated thickness of the freshwater lens for pre- and post-development conditions. For comparison purposes the volumes were also estimated using the frustum pyramid formula given below:

$$
\mathrm{V}=1 / 3\left[\mathrm{~A}_{1}+\mathrm{A}_{2}+\left(\mathrm{A}_{1} \mathrm{~A}_{2}\right)^{1 / 2}\right](\mathrm{h})
$$

where,

$$
\begin{aligned}
\mathrm{A}_{1}, \mathrm{~A}_{2} & \begin{array}{c}
\text { is the volume } \\
\text { are surface areas of upper and lower } \\
\text { boundaries of prism, and }
\end{array} \\
\mathrm{h} & \begin{array}{c}
\text { is the difference in height (depth) between } \\
\text { layers }
\end{array}
\end{aligned}
$$

Volume calculations using the frustum pyramid formula for pre-development conditions were higher than that obtained by use of a GIS. In the western area volume calculations were 10.3 percent higher [574,000 acre-feet (acre-ft) by frustum pyramid formula versus 515,000 acre-ft by GIS] and 6.6 percent higher in the eastern area [498,000 acre-ft by frustum pyramid formula versus 466,000 acre-ft by GIS]. The estimated total volume of freshwater in the aquifer contained below mean sea level datum for post- development conditions in the western area was 412,000 acre-ft by GIS and 460,000 acre-ft by the frustum pyramid formula (10.4 

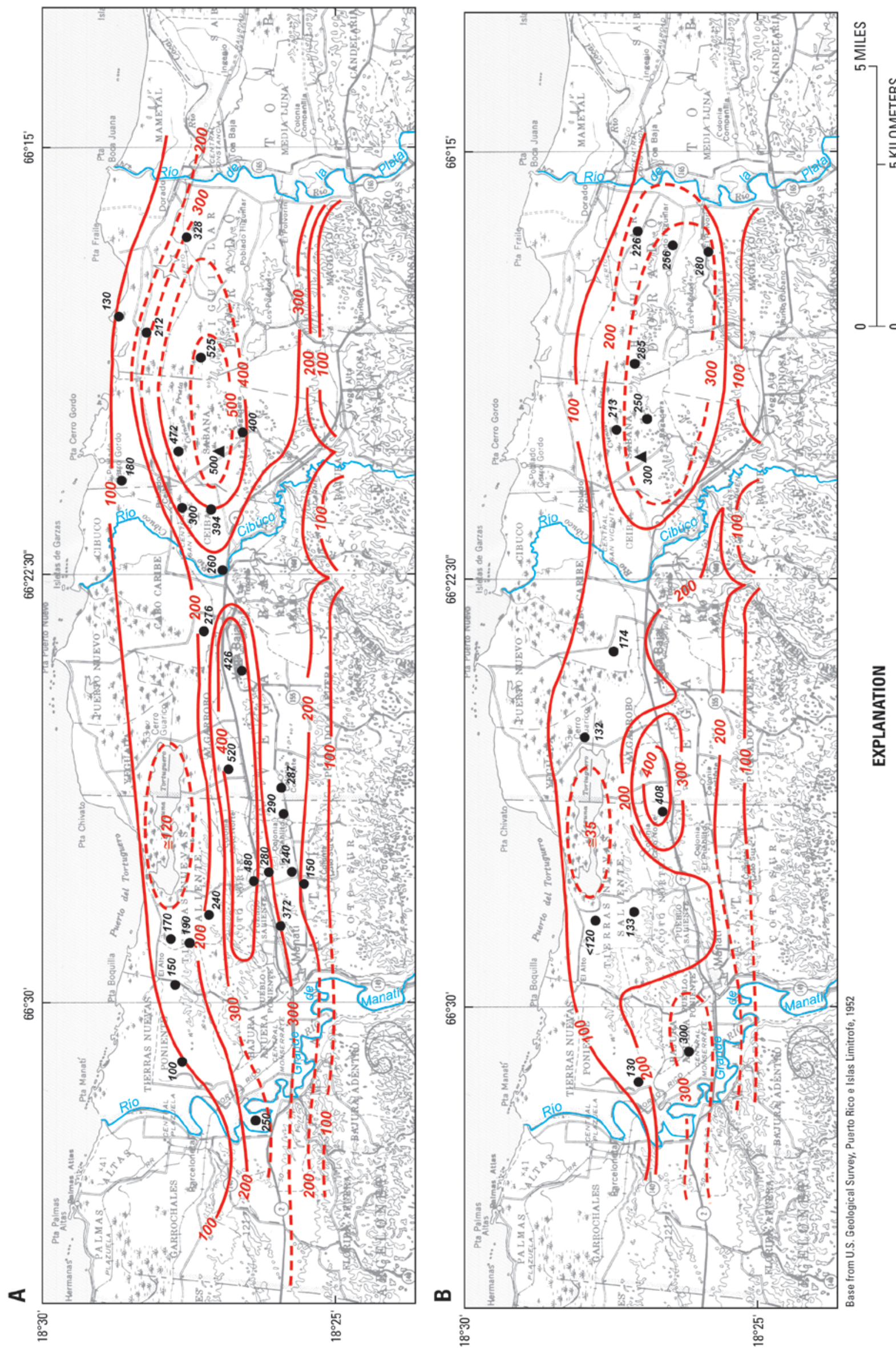

흠

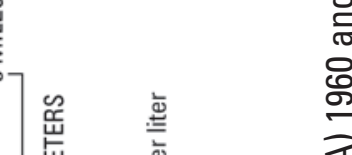

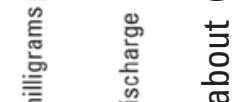

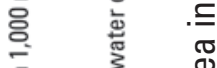

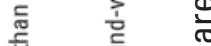

离 范

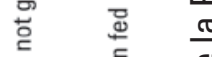

을 :

衰

棓

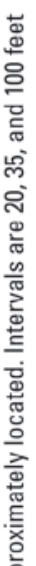

을

产 严

의

ले

管

$\frac{\pi}{3}$ 崩

喜帚

焉站离

.

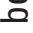

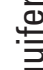




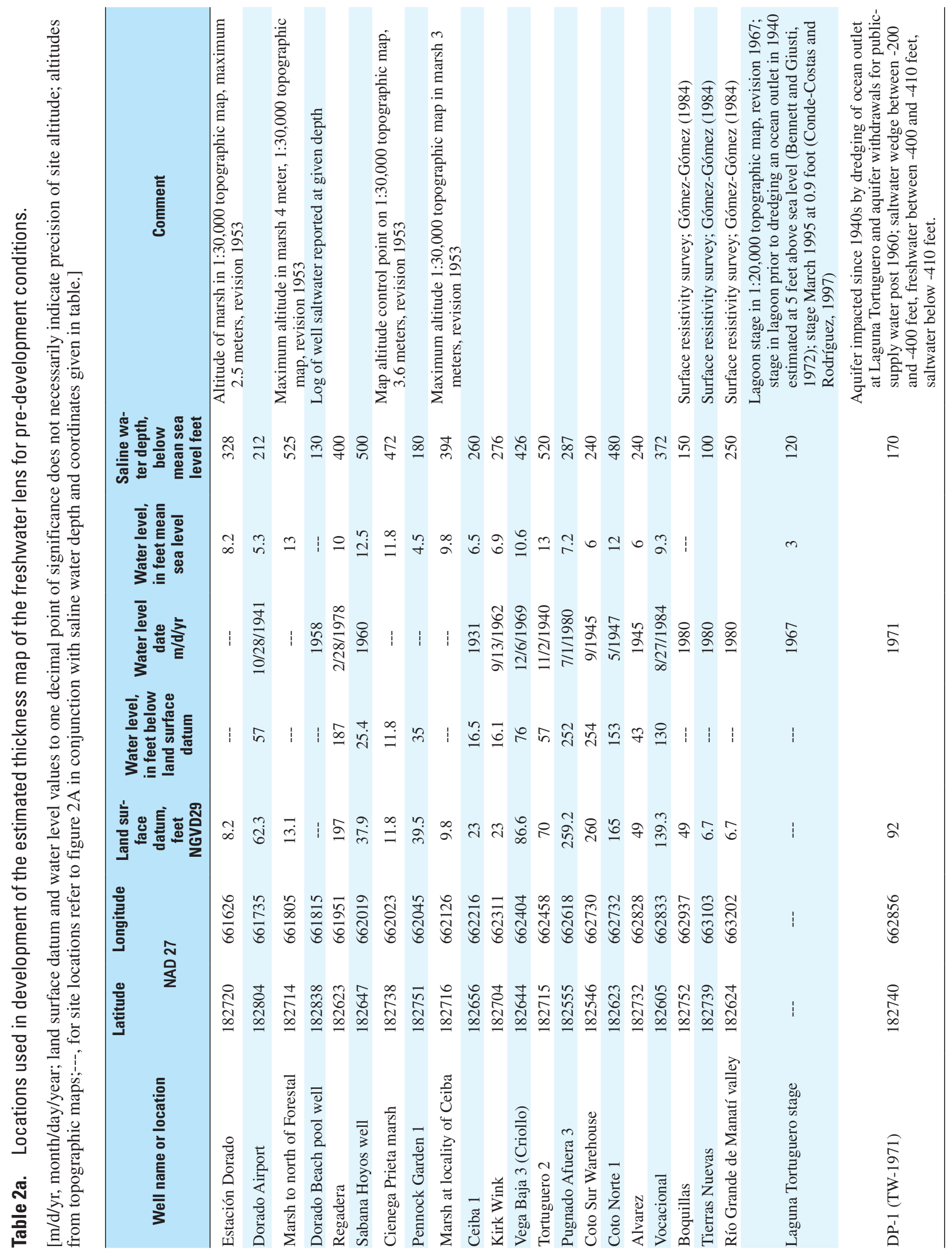




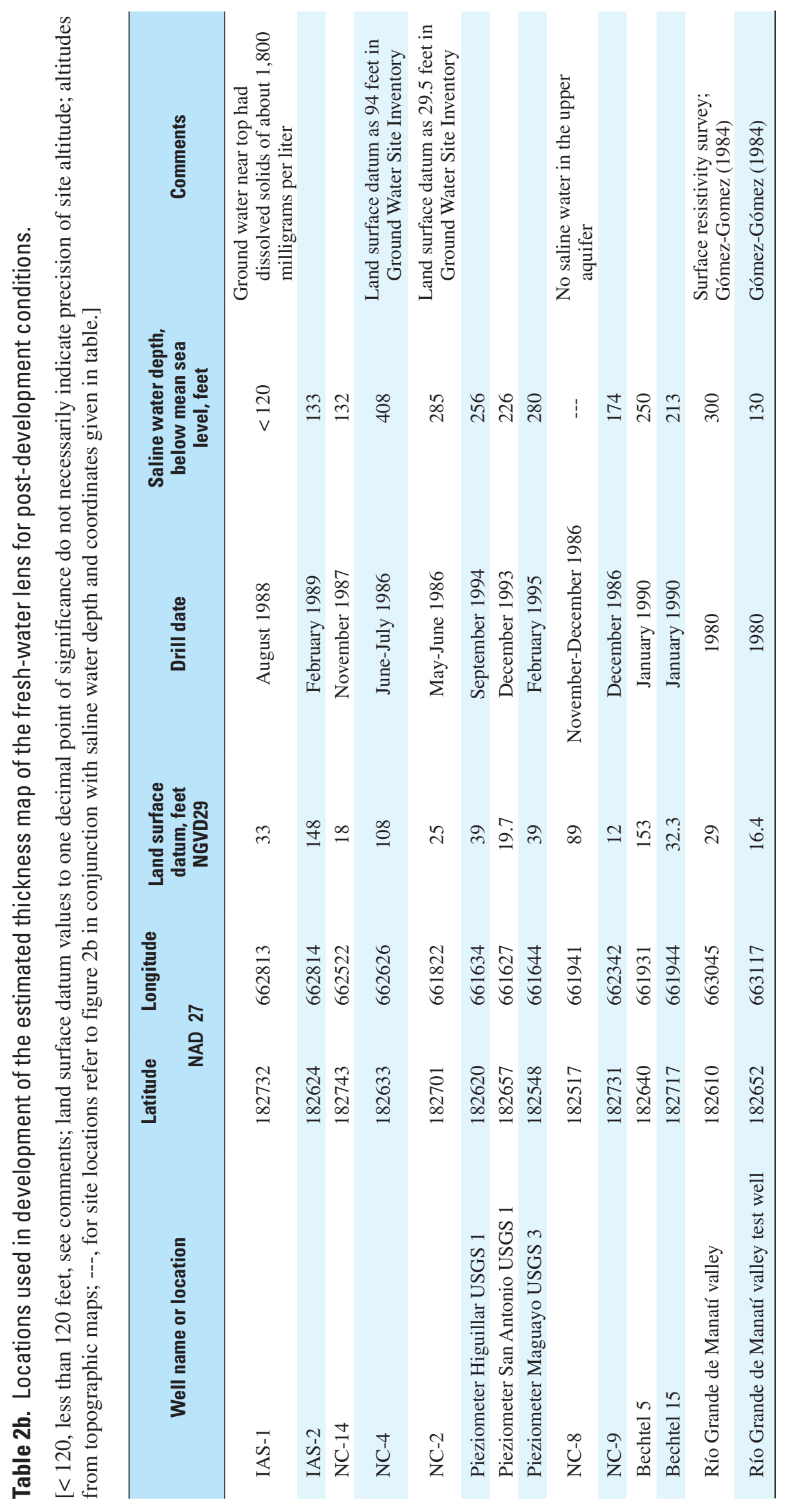


percent difference); and, for the eastern area, 287,000 acre-ft by GIS and 313,000 acre-ft by the frustum pyramid formula (8.3 percent difference). For purposes of this analysis, the GIS volumes are considered more precise. Freshwater volume change for each of the subareas was as follows: from 515,000 to 412,000 acre-ft in the western area, and from 466,000 to 287,000 acre-ft in the eastern area. In summary, the overall freshwater volume depletion below mean sea level datum was from 981,000 acre-ft in 1960 to 699,000 acre-ft in 1990.

Thus, the combined freshwater volume depleted below sea level datum in the aquifer may have constituted the source of about $7.5 \mathrm{Mgal} / \mathrm{d}(8,400$ acre-feet per year (acre-ft/yr)) of the estimated average ground-water withdrawal rate of $20 \mathrm{Mgal} / \mathrm{d}$ (22,000 acre$\mathrm{ft} / \mathrm{yr}$ ) between pre-development and post-development conditions.

\section{Effects of Fresh Ground-Water Volume Depletion in the Upper Aquifer}

Deterioration of water quality and unconstrained ground-water withdrawals have detrimentally affected areas of north-central Puerto Rico from Río Grande de Manatí to Río de la Plata (fig. 1). These major effects of ground-water storage depletion in the upper aquifer and the implications on public-water availability are discussed in the subsequent sections of this report.

\section{Deterioration of Ground-Water Quality}

Prior to large-scale development of ground-water resources in the upper aquifer, the available historical data on the quality of ground water indicate that it is reasonable to assume dissolved-solids concentrations generally ranged from 250 to $350 \mathrm{mg} / \mathrm{L}$ in wells drilled during the 1960s (Román-Más and Ramos-Ginés, 1988). As ground-water development lowered the water table, the freshwater lens thinned, leading to the upward and landward displacement of the freshwater-saltwater interface. Of the two conditions leading to an increase in dissolved-solids concentrations, the regional upward displacement of the freshwater-saltwater interface possibly has been the primary cause of most of the change in dissolved-solids concentrations documented at many wells and at Ojo de Agua spring in Vega Baja (fig. 9). An increase in dissolved-solids concentrations can be inferred from specific-conductance measurements obtained at public-supply wells and Ojo de Agua throughout the years. Specific conductance is directly related to dissolved-solids concentrations. In the upper aquifer, dissolved-solids concentration in ground water can be estimated on the basis of specific conductance as follows:

where

$$
\text { DSS = SC X } 0.58
$$

DSS is dissolved-solids sum of constituents, in milligrams per liter; and SC is specific conductance, in microsiemens per centimeter at 25 degrees Celsius.

Based on the historical specific conductance data, dissolved-solids concentrations increased to greater than $500 \mathrm{mg} / \mathrm{L}$ in virtually all of the public-supply wells north of latitude $18^{\circ} 26^{\prime}$ in the Río Grande de Manatí to Río de la Plata area by the year 2000 (fig. 9). The closure of some wells used as a potable water source may have been a result of these high dissolved-solids concentrations.

\section{Implications of Unconstrained Ground-Water Withdrawals}

Ground-water withdrawals from the upper aquifer in the Río Grande de Manatí to Río de la Plata study area historically have been the principal source of water for public-supply and self-supplied industrial uses. Groundwater withdrawals from the aquifer declined from a peak withdrawal rate of $33 \mathrm{Mgal} / \mathrm{d}$ in the 1980s to an average of $11.5 \mathrm{Mgal} / \mathrm{d}$ in 2002 . After the 1980s, the declines were attributed, in part, to contamination of ground water by organic solvents and nitrates, and encroachment of saline water. Saline-water encroachment caused by aquifer overdraft constitutes a major threat on future use of the aquifer as a source of potable-water supply. Aquifer overdraft has resulted in a decline of the water table by as much as $15 \mathrm{ft}$ and a regionally substantial upward displacement of the freshwater-saltwater interface of as much as $250 \mathrm{ft}$ between about 1960 and 1990. The amount of freshwater removed from aquifer storage below sea level datum within the approximately 50,600 acres of land surface overlying the aquifer north of latitude $18^{\circ} 25^{\prime}$ is estimated at 282,000 acre-ft, assuming an aquifer porosity of 0.10 . For comparative purposes this volume is equivalent to almost 10 times the large available storage capacity $(28,750$ acre-ft) of Lago La Plata in 1998 (Soler-López and others, 2000). Thinning of the freshwater lens below sea level datum contributed an estimated $7.5 \mathrm{Mgal} / \mathrm{d}$ of the approximate $20-\mathrm{Mgal} / \mathrm{d}$ average long-term mean annual withdrawal rate from the upper aquifer in the study area between about 1960 and 1990. Because most of the withdrawals have been used for public supply, the lost yield will have to be substituted by surface-water sources or expensive, alternative treatment of the ground water to achieve drinking-water standards (U.S. Environmental Protection 

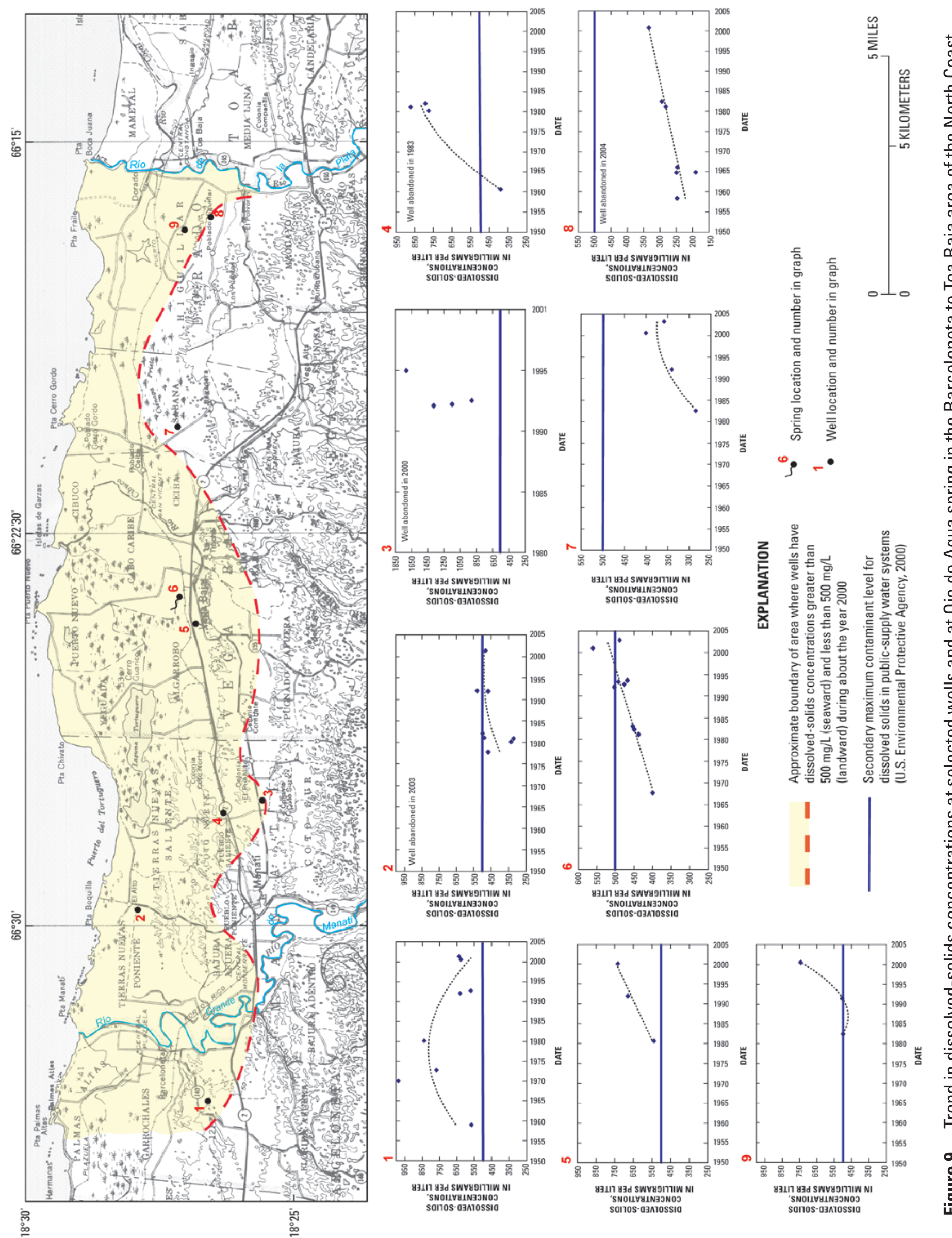

要

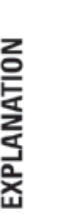

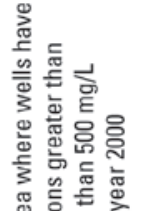

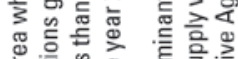

w记

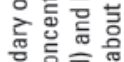

흘항ㅎㅁ

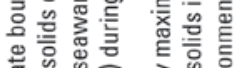

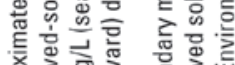

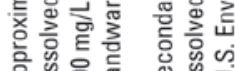

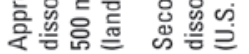

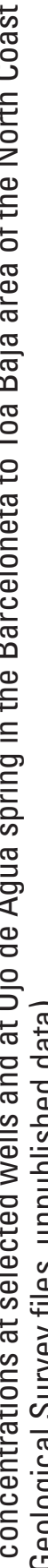

里

它

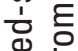

焉

幽高

些

$\subseteq$ 주

흥

일을



는 
Agency, 2000). At the estimated rate of freshwater depletion in the aquifer, many of the remaining largecapacity production wells yielding ground water with dissolved-solids concentrations equal to or greater than $500 \mathrm{mg} / \mathrm{L}$ probably will be abandoned by 2010 , with total withdrawals declining to less than $10 \mathrm{Mgal} / \mathrm{d}$.

\section{Summary}

An evaluation was made to determine the effects that ground-water withdrawals have had on the upper aquifer in north-central Puerto Rico (from Río Grande de Manatí to Río de la Plata) during the 20th century and beyond. The upper aquifer, which is part of the more extensive North Coast Limestone aquifer system has historically been the principal source of the publicsupply and self-supplied industrial water uses. Groundwater withdrawals for theses two major categories were estimated at less than 2.5 million gallons per day during the 1940s and reached a maximum of about 33 million gallons per day during the1980s. Withdrawals from the upper aquifer have been subsequently declining and can be attributed to aquifer contamination from industrial chemical spills and nitrate contamination from agricultural and domestic sources.

Digital, transient ground-water flow models have been developed to estimate the water balance of the upper aquifer between the Río Grande de Manatí and Río Cibuco (western area) and between the Río Cibuco and Río de la Plata (eastern area). The models helped to achieve improved knowledge on the occurrence and movement of ground water in the region. Two limitations of these flow models to anticipate future changes have been the assumption that: (1) a static freshwatersaltwater interface lies beneath the freshwater lens, and (2) aquifer recharge rate is constant. The consequence of using a constant-density freshwater model with a static freshwater-seawater interface is that the final change in freshwater volume of the aquifer after development and a new static equilibrium is achieved, cannot be estimated, since it would show only the change in volume from water-level decline.

Various sources of data were used to estimate the change in thickness of the freshwater lens below sea level datum for pre- and post-development (between about 1960 and 1990). These data were obtained from published literature, automated data bases, and files of the U.S. Geological Survey, Caribbean Water Science Center, relative to ground-water levels, test drilling, ground-water quality, and ground-water withdrawals. Dissolved-solids concentrations ranged from 250 to 350 milligrams per liter in wells penetrating the upper aquifer during the 1960s and increased to greater than 500 milligrams per liter in virtually all of the publicsupply wells by 2000 . During the 1960 s as ground-water development lowered the water table, the freshwater lens thinned and led to the upconing and landward movement of the freshwater-saltwater interface. The increase in dissolved-solids concentrations may have contributed to the closure of some wells used as a potable-water source. Ground-water withdrawals began on a large scale in the 1960s, peaking to about 33 million gallons per day in the 1980s and declining to about 11.5 million gallons per day in 2002. After the 1980s, the decline in withdrawals was attributed, in part, to contamination of ground water by organic solvents and nitrates and to saltwater encroachment. The depletion of fresh ground water from the freshwater lens below sea level datum may have contributed an estimated 282,000 acre-feet or about 7.5 million gallons per day of the mean annual withdrawal of 20 million gallons per day between preand post-development (between about 1960 and early 1990s). The anticipation is that many of the remaining large-capacity production wells yielding dissolved-solids concentrations equal to or less than 500 milligrams per liter will be abandoned by 2010 , with total withdrawals declining to less than 10 million gallons per day. 


\section{References Cited}

Bennet, G.D., and Giusti, E.V., 1972, Ground water in the Tortuguero area, Puerto Rico, as related to proposed harbor construction: U.S. Geological Survey Water-Resources Bulletin 10, 25 p.

Cherry, G.S., 2001, Simulation of flow in the Upper North Coast Limestone aquifer, Manatí-Vega Baja area, Puerto Rico: U.S. Geological Survey WaterResources Investigations Report 00-4266, 82 p.

Conde-Costas, Carlos, and Gómez-Gómez, Fernando, 1999, Assessment of nitrate contamination of the upper aquifer in the Manatí-Vega Baja area, Puerto Rico: U.S. Geological Survey Water-Resources Investigations Report 99-4040, 43 p.

Conde-Costas, Carlos, and Rodríguez, Gilberto, 1997, Potentiometric surface and hydrologic conditions of the upper aquifer in the Manatí-Vega Baja area, northcentral Puerto Rico, March 1995: U.S. Geological Survey Water-Resources Investigations Report 964184, 1 pl.

Dausman, Alyssa, and Langevin, C.D., 2004, Movement of the saltwater interface in the surficial aquifer system in response to hydrologic stresses and watermanagement practices, Broward County, Florida: U.S. Geological Survey Scientific Investigations Report 2004-5256, $73 \mathrm{p}$.

Fetter, C.W., Jr., 1980, Applied hydrogeology: Columbus, Ohio, Charles E. Merrill Publishing Co., $488 \mathrm{p}$.

Gómez-Gómez, Fernando, 1984, Water resources of the lower Río Grande de Manatí Valley, Puerto Rico: U.S. Geological Survey Water-Resources Investigations Report 83-4199, 40 p.

Gómez-Gómez, Fernando, 1997, Hurricane Hortense impact on ground water in Puerto Rico: U.S. Geological Survey Fact Sheet FS-012-97, 2 p.

Gómez-Gómez, Fernando, and Torres-Sierra, Heriberto, 1988, Hydrology and effects of development on the water-table aquifer in the Vega Alta quadrangle, Puerto Rico: U.S. Geological Survey Water-Resources Investigations Report 87-4105, 53 p.

Molina-Rivera, Wanda, 2005, Estimated water use in Puerto Rico, 2000: U.S. Geological Survey Open-File Report 2005-1201, 26 p.

Renken, R.A., Ward, W.C., Gill, I.P., Gómez-Gómez, Fernando, Rodríguez-Martínez, Jesús, and others, 2002, Geology and hydrogeology of the Caribbean Islands aquifer system of the Commonwealth of Puerto Rico and the U.S. Virgin Islands: U.S. Geological Survey Professional Paper 1419, 139 p., 5 pls.
Rodríguez-Martínez, Jesús, Scharlach, R.A., and TorresGonzález, Arturo, 1992, Geologic and hydrologic data collected at test holes NC-4 and NC-14, Manatí and Vega Baja, Puerto Rico: U.S. Geological Survey Open-File Report 92-126, 32 p.

Román-Más, Angel, and Ramos-Ginés, Orlando, 1988, Compilation of water-quality data for the North Coast Limestone aquifers, Puerto Rico, 1951 to 1987: U.S. Geological Survey Open-File Data Report 87-533, $133 \mathrm{p}$.

Sepúlveda, Nicasio, 1999, Ground-water flow, solute transport, and simulation of remedial alternatives for the water-table aquifer in Vega Alta, Puerto Rico: U.S. Geological Survey Water-Resources Investigations Report 97-4170, 96 p.

Soler-López, Luis, Webb, R.M.T., and Carrasquillo, Ramón, 2000, Sedimentation survey of Lago La Plata, Puerto Rico, October 1998: U.S. Geological Survey Water-Resources Investigations Report 00-4045, 23 p., 3 pls.

Torres-Sierra, Heriberto, 1985, Potentiometric surface of the upper limestone aquifer in the Dorado-Vega Alta area, north-central Puerto Rico, February 1983: U.S. Geological Survey Water-Resources Investigations Report 85-4268, 1 pl.

Troester, J.W., 1999, Geochemistry and hydrogeologic framework of the saline-freshwater interface and the calculation of net recharge in the Dorado area, northcentral Puerto Rico: U.S. Geological Survey WaterResources Investigations Report 94-4030, 36 p.

U.S. Environmental Protection Agency, 2000, Drinking water standards and health advisories: U.S. Environmental Protection Agency, Office of Water Publication, EPA 822-B-00-001, Washington, D.C., 16 p.

U.S. Environmental Protection Agency, 2004a, Superfund: accessed December 2004 at www.epa. gov/superfund/sites.

U.S. Environmental Protection Agency, 2004b, Puerto Rico National Priorities List Fact Sheets: accessed December 2004 at www.epa.gov/region02/superfund/ $\mathrm{npl} / \mathrm{prtoc} . \mathrm{htm}$.

W.C., Sharlach, R.A. and, Hartley, J.R., 1991, Controls on porosity and permeability in subsurface Tertiary carbonate rocks of northern Puerto Rico: in GómezGómez, Fernando, Quiñones -Aponte, Vicente and Johnson, A.I. eds., Regional aquifer systems of the United States-Aquifers of the Caribbean Islands: American Water-Resources Association Monograph Series No. 15, p. 17-23. 


\section{APPENDIX}


Appendix 1. Specific conductivity variation with depth of penetration during test well drilling in upper aquifer.

[Land surface datum from 1:20,000 scale U.S. Geological Survey topographic maps; Specific conductivity in microsiemens per centimeter at 25 degrees Celsius; FW, freshwater (specific conductivity less than 1,800)]

\begin{tabular}{|c|c|c|c|c|c|c|}
\hline \multirow[t]{8}{*}{ IAS-1 } & 182732 & 662813 & 33 & 154 & 3100 & -154 \\
\hline & & & & 188 & 4600 & -188 \\
\hline & & & & 195 & 7000 & -195 \\
\hline & & & & 216 & 24000 & -216 \\
\hline & & & & 228 & 32000 & -228 \\
\hline & & & & 237 & 40000 & -237 \\
\hline & & & & 271 & 43500 & -271 \\
\hline & & & & 296 & 45000 & -296 \\
\hline \multirow{6}{*}{ IAS-2 } & & & & 337 & 13000 & -337 \\
\hline & & & & 346 & 16000 & -346 \\
\hline & & & & 366 & 35000 & -366 \\
\hline & & & & 377 & 40000 & -377 \\
\hline & & & & 396 & 48000 & -396 \\
\hline & & & & 397 & 48500 & -397 \\
\hline \multirow[t]{20}{*}{ NC-2 } & 182701 & 661822 & 25 & 25 & 700 & -25 \\
\hline & & & & 52 & 705 & -52 \\
\hline & & & & 75 & 750 & -75 \\
\hline & & & & 112 & 760 & -112 \\
\hline & & & & 275 & 750 & -275 \\
\hline & & & & 290 & 800 & -290 \\
\hline & & & & 298 & 910 & -298 \\
\hline & & & & 300 & 1150 & -300 \\
\hline & & & & 310 & 1350 & -310 \\
\hline & & & & 312 & 7000 & -312 \\
\hline & & & & 315 & 9000 & -315 \\
\hline & & & & 320 & 16800 & -320 \\
\hline & & & & 325 & 18000 & -325 \\
\hline & & & & 340 & 17000 & -340 \\
\hline & & & & 352 & 23000 & -352 \\
\hline & & & & 360 & 24000 & -360 \\
\hline & & & & 375 & 29500 & -375 \\
\hline & & & & 390 & 33000 & -390 \\
\hline & & & & 400 & 33500 & -400 \\
\hline & & & & 420 & 36500 & -420 \\
\hline
\end{tabular}


Appendix 1. Specific conductivity variation with depth of penetration during test well drilling in upper aquifer.-Continued

[Land surface datum from 1:20,000 scale U.S. Geological Survey topographic maps; Specific conductivity in microsiemens per centimeter at 25 degrees Celsius; FW, freshwater (specific conductivity less than 1,800)]

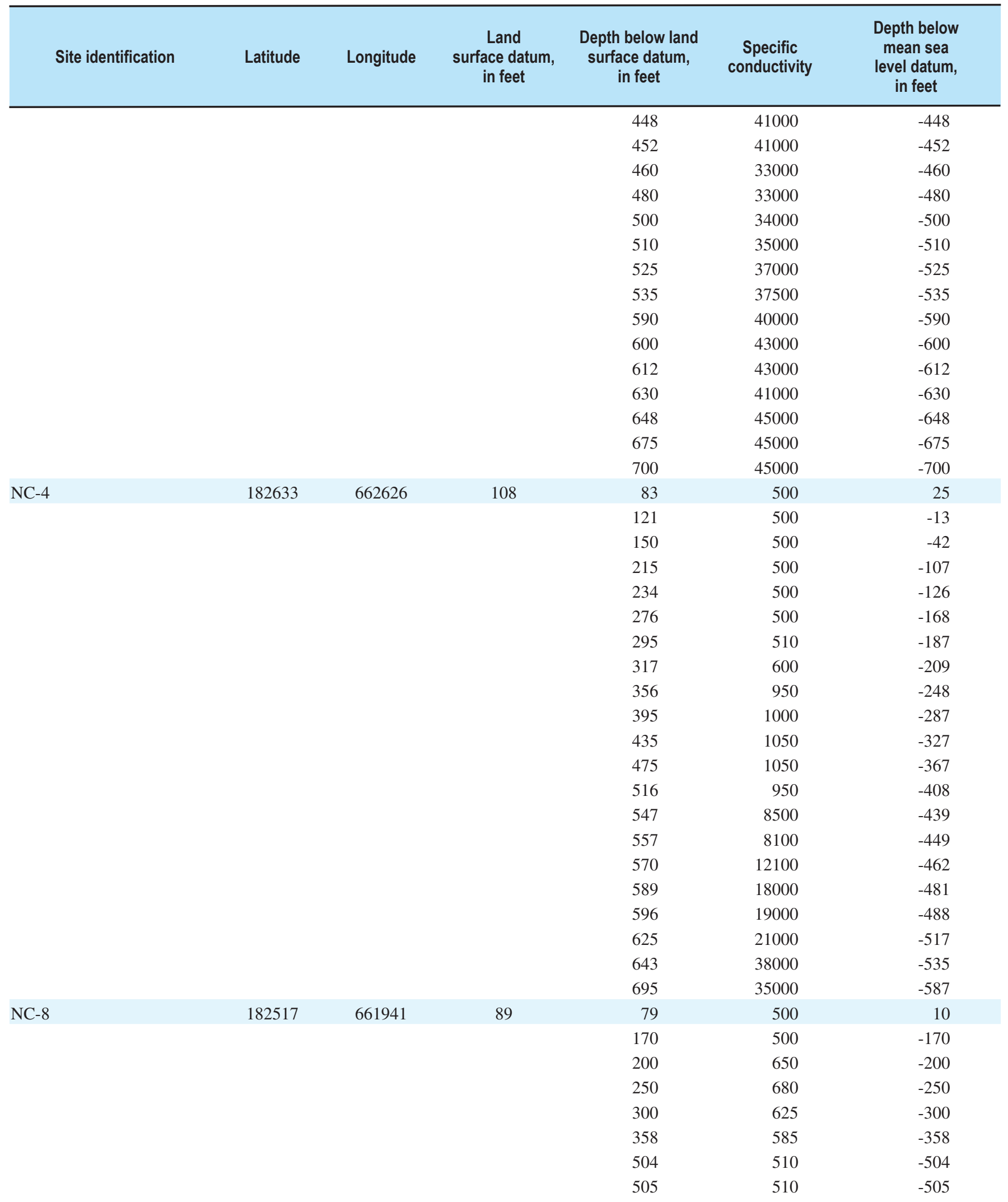




\section{Estimation of the Change in Freshwater Volume in the North Coast Limestone Upper Aquifer of Puerto Rico}

Appendix 1. Specific conductivity variation with depth of penetration during test well drilling in upper aquifer.-Continued

[Land surface datum from 1:20,000 scale U.S. Geological Survey topographic maps; Specific conductivity in microsiemens per centimeter at 25 degrees Celsius; FW, freshwater (specific conductivity less than 1,800)]

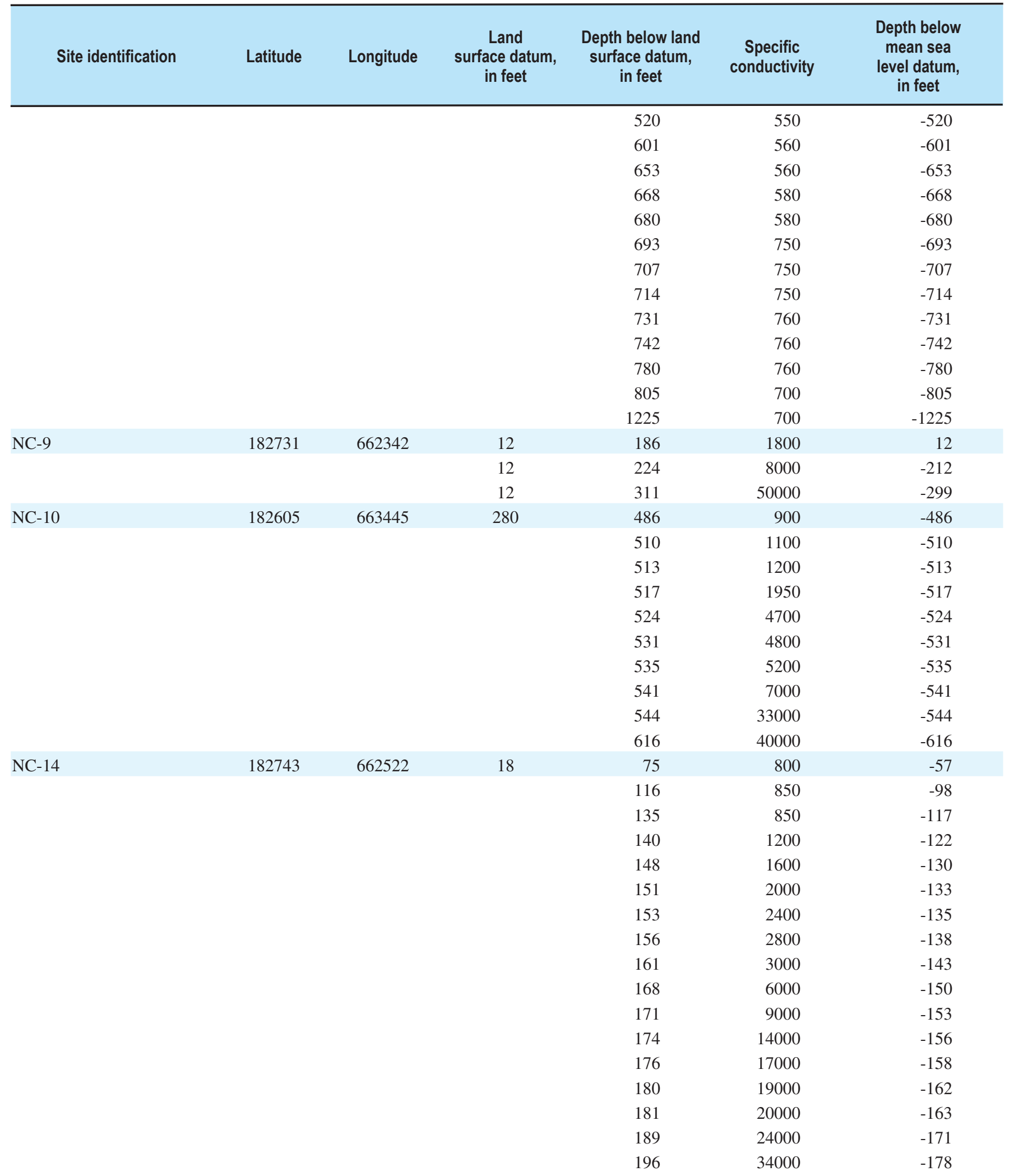


Appendix 1. Specific conductivity variation with depth of penetration during test well drilling in upper aquifer.-Continued

[Land surface datum from 1:20,000 scale U.S. Geological Survey topographic maps; Specific conductivity in microsiemens per centimeter at 25 degrees Celsius; FW, freshwater (specific conductivity less than 1,800)]

\begin{tabular}{|c|c|c|c|c|c|c|}
\hline & & & & 223 & 42000 & -205 \\
\hline & & & & 236 & 47500 & -218 \\
\hline & & & & 314 & 49000 & -296 \\
\hline \multirow{9}{*}{ Higuillar 1 test well } & & & & 312 & 3000 & -273 \\
\hline & & & & 321 & 3100 & -282 \\
\hline & & & & 328 & 4700 & -289 \\
\hline & & & & 340 & 4700 & -301 \\
\hline & & & & 350 & 10000 & -311 \\
\hline & & & & 400 & 10000 & -361 \\
\hline & & & & 410 & 12000 & -371 \\
\hline & & & & 459 & 22000 & -420 \\
\hline & & & & 482 & 27000 & -443 \\
\hline \multirow[t]{3}{*}{ San Antonio 1 test well } & 182657 & 661627 & 19.7 & 246 & FW & -226.3 \\
\hline & & & & 260 & 10000 & -240.3 \\
\hline & & & & 285 & 45000 & -265.3 \\
\hline \multirow[t]{6}{*}{ Maguayo 3 test well } & 182548 & 661644 & 39 & 13 & $\mathrm{FW}$ & 26 \\
\hline & & & & 279 & FW & -240 \\
\hline & & & & 318 & 2000 & -279 \\
\hline & & & & 385 & 19000 & -346 \\
\hline & & & & 397 & 19000 & -358 \\
\hline & & & & 427 & 21000 & -388 \\
\hline \multirow[t]{4}{*}{ Bechtel Multiport well 5} & 182640 & 661931 & 153 & 116.2 & 554 & -36.8 \\
\hline & & & & -116.8 & 546 & -116.8 \\
\hline & & & & -181.8 & 546 & -181.8 \\
\hline & & & & -256.8 & 1856 & -256.8 \\
\hline \multirow[t]{5}{*}{ Bechtel Multiport well 15} & 182717 & 661944 & 32.3 & -3.9 & 669 & -36.2 \\
\hline & & & & -101.2 & 937 & -101.2 \\
\hline & & & & -213.2 & 1972 & -213.2 \\
\hline & & & & -268.2 & 24736 & -268.2 \\
\hline & & & & -283.2 & 41093 & -283.2 \\
\hline
\end{tabular}

Note: Specific conductivity calculated from chloride data using relation for ground-water samples in the Puerto Rico Aqueduct and Sewer Authority wells between Dorado and Manatí for chloride-specific conductivity relation at both Bechtel wells. 
Appendix 1. Specific conductivity variation with depth of penetration during test well drilling in upper aquifer.-Continued

[Land surface datum from 1:20,000 scale U.S. Geological Survey topographic maps; Specific conductivity in microsiemens per centimeter at 25 degrees Celsius; FW, freshwater (specific conductivity less than 1,800)]

\begin{tabular}{|c|c|c|c|c|c|c|}
\hline \multirow[t]{13}{*}{ DP-1 (TW-1971) } & 182740 & 662856 & 92 & 100 & 1080 & -100 \\
\hline & & & & 125 & 1060 & -125 \\
\hline & & & & 175 & 1080 & -175 \\
\hline & & & & 200 & 1110 & -200 \\
\hline & & & & 213 & 1320 & -213 \\
\hline & & & & 238 & 1070 & -238 \\
\hline & & & & 263 & 1020 & -263 \\
\hline & & & & 413 & 43600 & -413 \\
\hline & & & & 438 & 23300 & -438 \\
\hline & & & & 463 & 17100 & -463 \\
\hline & & & & 488 & 43700 & -488 \\
\hline & & & & 513 & 1880 & -513 \\
\hline & & & & 538 & 43900 & -538 \\
\hline NC-13 & 182630 & 661223 & 3.3 & & $\begin{array}{c}\text { FW to } 100 \text { feet } \\
\text { below land } \\
\text { surface }\end{array}$ & -96.7 \\
\hline
\end{tabular}

